

\title{
Seabird colonies as relevant sources of pollutants in Antarctic ecosystems: Part 1 - Trace elements
} C.V.Z. V Z Cipro, P. Bustamante, M.V. V Petry, R.C. C Montone

\section{To cite this version:}

C.V.Z. V Z Cipro, P. Bustamante, M.V. V Petry, R.C. C Montone. Seabird colonies as relevant sources of pollutants in Antarctic ecosystems: Part 1 - Trace elements. Chemosphere, 2018, 204, pp.535-547. 10.1016/j.chemosphere.2018.02.048 . hal-02014986

\section{HAL Id: hal-02014986 \\ https://hal.science/hal-02014986}

Submitted on 4 Mar 2019

HAL is a multi-disciplinary open access archive for the deposit and dissemination of scientific research documents, whether they are published or not. The documents may come from teaching and research institutions in France or abroad, or from public or private research centers.
L'archive ouverte pluridisciplinaire HAL, est destinée au dépôt et à la diffusion de documents scientifiques de niveau recherche, publiés ou non, émanant des établissements d'enseignement et de recherche français ou étrangers, des laboratoires publics ou privés. 
Seabird colonies as relevant sources of pollutants in Antarctic ecosystems: Part 1 - Trace elements

Cipro, C.V.Z. ${ }^{1,2^{*}}$, Bustamante, P. ${ }^{2}$, Petry, M.V. ${ }^{3}$ and Montone, R.C. ${ }^{1}$

${ }^{1}$ Laboratório de Química Orgânica Marinha, Instituto Oceanográfico (LabQOM),

Universidade de São Paulo, Praça do Oceanográfico n 191, 05508-120 São Paulo, SP, Brazil

${ }^{2}$ Littoral Environnement et Sociétés (LIENSs), UMR 7266, CNRS-Université de La Rochelle, 2 rue Olympe de Gouges 17042 La Rochelle Cedex 01, France

${ }^{3}$ Laboratório de Ornitologia e Animais Marinhos, Universidade do Vale do Rio dos Sinos, Av. Unisinos n 950, Cristo Rei, São Leopoldo, Rio Grande do Sul, 93022-000, Brazil

* Corresponding author: caiovzc@ usp.br 


\section{Highlights}

- Seabird colonies are verified as possible secondary sources of trace elements.

- Soil and vegetation samples in/around colonies are compared to controls away from them.

- Results suggest colonies act as sources of $\mathrm{Cd}, \mathrm{Hg}$ and likely As, Se and Zn.

- Isotopes confirm the animal-derived organic matter influence on colony sites.

- Other local Hg sources, likely research stations, could also be inferred. 
Abstract: Global distillation is classically pointed as the biggest responsible for contaminant inputs in Polar ecosystems. Mercury (Hg) and other trace elements (TEs) also present natural sources, whereas the biologically mediated input is typically ignored. However, bioaccumulation and biomagnification combined with the fact that seabirds gather in large numbers into large colonies and excrete on land might represent an important local TEs input. A previous work suggested these colonies as sources of not only nutrients, but also organic contaminants. To evaluate a similar hypothesis for TEs, samples of lichen $(n=55)$, mosses $(n$ $=58)$ and soil $(\mathrm{n}=37)$ were collected in 13 locations within the South Shetlands Archipelago during the austral summers of 2013-14 and 2014-15. They were divided in: "colony" (within the colony itself for soil and bordering it for vegetation) and "control" (at least 50m away from colony interference), analysed for TEs (As, $\mathrm{Cd}, \mathrm{Co}, \mathrm{Cr}, \mathrm{Cu}, \mathrm{Fe}, \mathrm{Hg}, \mathrm{Mn}, \mathrm{Ni}, \mathrm{Pb}, \mathrm{Se}, \mathrm{V}$, and Zn) and stable isotopes ( $\mathrm{C}$ and $\mathrm{N}$ ). In most cases, soil seems the best matrix to assess colonies as TEs sources, as it presented more differences between control/colony sites than vegetation. Colonies are clearly local sources of organic matter, $\mathrm{Cd}, \mathrm{Hg}$ and likely of $\mathrm{As}, \mathrm{Se}$ and $\mathrm{Zn}$. Conversely, $\mathrm{Co}, \mathrm{Cr}, \mathrm{Ni}$ and $\mathrm{Pb}$ come presumably from other sources, natural or anthropogenic. In general, isotopes were more useful for interpreting vegetation data due to fractionation of absorbed animal-derived organic matter. Other local $\mathrm{Hg}$ sources could be inferred from high levels in control sites, location and wind patterns.

Keywords: Antarctica, secondary sources, stable isotopes, heavy metals, inorganic contaminants, trace elements 


\section{Introduction}

"Global distillation", the process by which volatile contaminants evaporate in warmer regions, undergo long-range transport and condensate in colder regions, is classically pointed as the biggest responsible for contaminant inputs in Polar ecosystems. Besides this process, mercury (Hg), a toxic non-essential element (Tan et al., 2009) and other trace elements present natural sources as well, in a lesser scale, which could have local significance (e.g. Mão de Ferro et al., 2013). The biologically mediated transport, however, is typically ignored (Blais et al., 2007, 2005), but might represent an important input at the local (Huang et al., 2014) or regional (Blais et al., 2007) scales, not only in polar environments but also in semi-arid ones for instance (Garcia et al., 2002). This transfer from the sea to the land is reported not only for trace elements, but to other contaminants as well (Negoita et al., 2003; Roosens et al., 2007). Nevertheless, the concentration of non-essential trace elements along the life of organisms (bioaccumulation), and also along the trophic webs (biomagnification), combined with the fact that individuals gather in large numbers into large colonies for some species and excrete on land, are particularly characteristic for seabirds during the reproductive season, resulting in considerable input in these locations.

In maritime Antarctica, seabird colonies represent the major source of nutrients for terrestrial ecosystems (Smykla et al., 2007). Both extant and abandoned colonies (Liu et al., 2006; Outridge et al., 2016; Tatur et al., 1997) play this role due to not only the guano, but also to eggs (Brasso et al., 2012), bird tissues and prey present in these structures (Emslie et al., 2014). Nutrients distribution and availability typically induce a zonation pattern of ornithogenic exposed soil within the colony followed by green algae/cyanobacteria, Antarctic hair-grass, mosses and lichens, in this order, as the distance to the colony increases (Smykla et al., 2007). However, this input of nutrients given by bird colonies comes along with an input of contaminants as well, by a more direct influence of the contaminants present in the excretion itself (Espejo et al., 2014; Nie et al., 2012; Rudolph et al., 2016) or of the transport of trace elements during biogeochemical cycles (e.g. Malandrino et al., 2009; Zheng et al., 2015). In an analogous manner, runoff water is known to have a key influence in marine primary production (Anderson and Polis, 1999) and in carrying trace elements (Bettinelli et al., 2000) to be absorbed by marine life (Cipro et al., 2018)..

Several studies pointed the suitability of both soil (Prus et al., 2015; Sysalová et al., 2013) and vegetation as good indicator matrixes for both organic and inorganic contaminants (e.g. Lim et al., 2009; Wojtuń et al., 2013; Zvěřina et al., 2014) as well as some others that 
compare soil, lichens and/or mosses (e.g. Park et al., 2010; Tarcau et al., 2013). However, only a few publications proposed such colonies (e.g. Choy et al., 2010; Cipro et al., 2011; Roosens et al., 2007) or carcasses (e.g. Zvěřina et al., 2016) as an important secondary contaminants source for terrestrial or coastal Polar ecosystems. In addition, studies pointing out the concentration of trace elements in seabird faeces (Celis et al., 2015; Espejo et al., 2014; Finger et al., 2017) reinforce the fact that this input should be more deeply explored.

In a previous study using vegetation as indicator (Cipro et al., 2011), we showed that the degradation of animal derived organic matter (seabird colonies for instance) could constitute non-negligible sources of organic contaminants. In this context, the present work constitutes a geographical and ecological enlargement of scope and reach as well as a refinement of our previous work (Cipro et al., 2011). Differently from the studies pubished in the open literature, our work aims to evaluate the influence of seabird colonies as secondary sources of trace elements using both soil and vegetation as indicators in maritime in several Antarctic terrestrial ecosystems considering geographical variation, distance to the colonies and the use of different seabird species with different feeding ecology strategies. Moreover, the nature of the different matrixes plays a major role in understanding how these contaminants are exposed to these matrixes via different pathways.

\section{Material and methods}

\section{Sampling}

Samples of lichen $(n=55)$, mosses $(n=58)$ and soils $(n=37)$, were collected in 13 locations within the South Shetlands Archipelago in the austral summers of 2013-14 and 201415 during cruises of the Brazilian Antarctic Programme and divided in two types: "colony" (within the colony itself for soil and within the colony or bordering it for vegetation) and "control" (at least 50m away from the respectively closest colony. Lichens and soil were collected in higher elevations than the colony, whereas mosses, due to their water-dependency, were lower). Samples were collected with plastic gear (spoons and tweezers) firstly rinsed in an acid bath (35 $\mathrm{mL} \mathrm{L}^{-1}$ nitric acid, $50 \mathrm{~mL} \mathrm{~L}^{-1}$ hydrochloric acid), then further rinsed with Milli$\mathrm{Q}$ water. Soil samples were dug no deeper than $5 \mathrm{~cm}$. They were chosen at the field mainly by their availability, avoiding fresh faeces which could mask the results for the formed ornithogenic soil.

In some cases, samples were collected in more than one spot in each area of interest, which was described by the "main location" and "specific location" labels. Thus, the 
comparison between control and colony sites was made within the same specific location, when available, otherwise the closest control sample within the same main location was adopted.

Once collected, samples were stored in hermetically sealed plastic bags, frozen aboard $\left(-20^{\circ} \mathrm{C}\right)$ and kept frozen until arrival at the Marine Organic Chemistry Laboratory (LabQOM, University of São Paulo/Brazil), where they underwent lyophilisation. Vegetation species were identified by Prof. Jair Putzke (Universidade Federal do Pampa, São Gabriel, Brazil). Samples were then sent to the University of La Rochelle, France, where they were ground to a fine powder in a ceramic mortar before analyses. Soil samples were sifted (1 $\mathrm{mm}$ mesh) after freezedrying in order to remove larger rock fragments and debris. Soil samples were not ground nor before nor after drying and sifting.

\section{Analyses}

Trace element analyses were performed in the "Plateforme Analyses Élementaires" ofLIENSs and stable isotope analyses (SIA) were performed in the "Plateforme Analyses Isotopiques" of LIENSs, according to their own protocols, further detailed. Hg analyses were carried out with an Automatic Mercury Analyser spectrophotometer, ALTEC AMA 254, which does not require an acid digestion of the samples following Blévin et al. (2013). According to the $\mathrm{Hg}$ content, limit of detection and calibration curves, aliquots ranging from 4 to $61 \mathrm{mg}$ of freeze-dried sample were directly analysed after being inserted in the oven of the apparatus. After drying, the samples were heated under an oxygen atmosphere for $3 \mathrm{~min}$, and the $\mathrm{Hg}$ liberated and subsequently amalgamated on an Au-net. The net was then heated to liberate the collected $\mathrm{Hg}$, which was measured by Atomic Absorption Spectrometry. Accuracy and reproducibility of the method were tested using dogfish liver (DOLT-2) and muscle (DORM2) and lobster hepatopancreas (TORT-2) (National Research Council, Canada) reference standards. Standard and blanks were analysed along with each set of samples, and recoveries of the certified values and recoveries of $\mathrm{Hg}$ ranged from 87 to $94 \%$. Concentrations are expressed in dry weight in order to compensate eventual moisture loss during freezing and to facilitate comparison between tissues and with other studies. Blanks were analysed at the beginning and end of each set of samples, and the detection limit of the method was $0.005 \mu \mathrm{g}$ $\mathrm{g}^{-1}$ dry weight (dw).

The analyses of the remaining trace elements (As, $\mathrm{Cd}, \mathrm{Co}, \mathrm{Cr}, \mathrm{Cu}, \mathrm{Fe}, \mathrm{Mn}, \mathrm{Ni}, \mathrm{Pb}, \mathrm{Se}$, $\mathrm{V}$, and $\mathrm{Zn}$ ) were performed as described by Lucia et al. (2016): analyses were carried out using a Varian Vista-Pro ICP-OES and a Thermo Fisher Scientific XSeries 2 ICP-MS. Aliquots of 
the samples (from 90 to $255 \mathrm{mg}$ ) were digested with $6 \mathrm{ml} 67-70 \% \mathrm{HNO}_{3}$ and $2 \mathrm{ml} \mathrm{34-37 \%}$ $\mathrm{HCl}$ (Fisher Scientific, trace element grade quality). This acidic digestion was performed overnight at room temperature, then using a Milestone microwave (30 min with constantly increasing temperature up to $120^{\circ} \mathrm{C}$, then $15 \mathrm{~min}$ at this maximal temperature). Each sample was completed to $50 \mathrm{ml}$ with milli-Q water. Three control samples (two Certified Reference Materials, CRMs, and one blank) treated and analysed in the same way as the samples, were included in each analytical batch. CRMs were dogfish liver DOLT-4 (NRCC) and lobster hepatopancreas TORT-3 (NRCC). Mean recovery rates were, in regard to those CRMs, of $101 \%$ for As, $99 \%$ for $\mathrm{Cd}, 101 \%$ for $\mathrm{Co}, 94 \%$ for $\mathrm{Cr}, 96 \%$ for $\mathrm{Cu}, 94 \%$ for $\mathrm{Fe}, 91 \%$ for $\mathrm{Mn}, 99 \%$ for $\mathrm{Ni}, 89 \%$ for $\mathrm{Pb}, 99 \%$ for $\mathrm{Se}, 92 \%$ for $\mathrm{V}$ and $101 \%$ for $\mathrm{Zn}$. Trace element concentrations are also expressed in $\mu \mathrm{g} \mathrm{g}^{-1} \mathrm{dw}$. Measurements were also validated by IAEA inter-calibration exercises (Coquery et al., 2001).

SIA was performed as described in previous literature (Chouvelon et al., 2012; Cipro et al., 2017), with some modifications, especially the decarbonation of soil samples. Due to the negligible lipid content and influence in the results verified during previous studies (Cipro et al., 2017, 2011), samples have not undergone delipidation. Soil samples, however, have undergone a decarbonation procedure to avoid the interference of carbonates, which are depleted in ${ }^{13} \mathrm{C}$ and could represent a bias in data interpretation. The decarbonation was as follows: up to $100 \mathrm{mg}$ of ground sample were put in a glass vial, $1 \mathrm{~mL}$ of $\mathrm{HCl} 0.1 \mathrm{~N}$ were added and the vial was placed in a microwave bath, observing bubble formation as an indicator of carbonates digestion. After one minute, $100 \mu 1$ of the same acid was added to verify that no more bubble formation was shown. If that was the case, this first step was repeated many times as needed. Next, the vials were put in a $60^{\circ} \mathrm{C}$ dry bath (Techne) coupled to an evaporation system consisting of tubes gently blowing filtered analytical quality compressed air into the vials overnight in order to evaporate the liquid acidic phase. The following day, samples were recovered with $1 \mathrm{~mL}$ of Milli-Q water, homogenised in a microwave bath for 1 minute, frozen and finally lyophilised.

SIA themselves were performed as follows: an aliquot of ground prepared sample $(0.8$ up to $1.5 \mathrm{mg}$ for vegetation, 1.5 to $8 \mathrm{mg}$ for colony soil, 8 to $16 \mathrm{mg}$ for control soil) was encapsulated in tin cups and injected in a Thermo Scientific Delta V Advantage ConFlo IV interface (NoBlank and SmartEA) coupled to a Thermo Scientific Flash EA1112 Elemental Analyser. Pee Dee Belemnite and atmospheric nitrogen were used as standards for calculation 
of $\delta^{13} \mathrm{C}$ and $\delta^{15} \mathrm{~N}$, respectively. Based on replicate measurements of internal laboratory standards, experimental precision is of $\pm 0.15 \%$ and $\pm 0.20 \%$ for $\delta^{13} \mathrm{C}$ and $\delta^{15} \mathrm{~N}$, respectively.

\section{Statistics}

Statistics were performed using Microsoft Excel and Statsoft Statistica 12 and 13. Before analyses, data were checked for normality of distribution and homogeneity of variances using Shapiro-Wilk and Brown-Forsythe tests, respectively. Statistically significant results are set at $\square=0.05$ unless stated otherwise. Differences of colony and control datasets were assessed by means of t-tests and Pearson/Spearman correlations are chosen due to their linear/monotonic nature and not necessarily to parametric/non-parametric analyses.

Normal distribution and log-link function generalized linear models (GLM) were built as follows: trace element concentrations as the dependent variable; matrix, main location, specific location, colony species and matrix species as categorical factors; $\delta^{13} \mathrm{C}, \delta^{15} \mathrm{~N}, \% \mathrm{C}$ and $\% \mathrm{~N}$ as continuous predictors. Biologically relevant models were constructed incorporating the different variables and their interactions taking the care of removing continuous variables that were significantly correlated before model building in each dataset and its subsets as well. Model selection was based on Akaïke's Information Criteria adjusted for small sample sizes (AICc). The model with the lowest AICc value was considered to be the most accurate. Models with AICc values differing by less than 2 have a similar level of support in the data, and the model including the least number of parameters can be regarded as the most accurate, according to the principle of parsimony (Burnham and Anderson, 2002). Overall model support was assessed using Akaike weights $\left(\mathrm{w}_{\mathrm{i}}\right)$, following Johnson and Omland (2004). Residual ( $\mathrm{R}^{2} \mathrm{adj}$ ) analyses should be restricted to description and not be used in model selection (Burnham and Anderson, 2002). Only models with AICc values differing by less than 10 are presented.

\section{Results and discussion}

Mean results for selected trace elements ( $\mathrm{As}, \mathrm{Cd}, \mathrm{Cu}, \mathrm{Hg}, \mathrm{Pb}, \mathrm{Se}$, and $\mathrm{Zn}$ ), vegetation species (when suitable), bird colony species, location (both main and specific, which refers to a subpart of the main one when suitable), SIA, C and $\mathrm{N}$ content and sampling numbers are given in Table 1. It should be stated by now that more emphasis is to be given to $\mathrm{Cd}$ and $\mathrm{Hg}$ data interpretation due to their ecotoxicological relevance in not only terrestrial ecosystems, but in marine ones as well (e.g. Tsui and Wang, 2004). For the same reason (see Olech et al., 1998), 
$\mathrm{Pb}$ is briefly discussed in the proper section. The whole dataset containing all trace elements is presented as supplementary material for editorial reasons. A possible interference of pinnipeds land excretion has not been taken into consideration for two reasons: from field experience, only one of the sampling locations had pinnipeds presence (mostly the Southern Elephant Seal, Mirounga leonina, in Livingston Island), which remain close to the water and do not go uphill as most birds do, so the excreta might end up washed away. And secondly, haulout periods for pinnipeds in general and for this species in particular are not as prolonged as for seabirds (Hindell and Burton, 1988; Lake et al., 1997; Slip and Burton, 1999)

In regard to $\mathrm{Hg}$, mean results show some prevailing patterns. For soils, control samples were less contaminated than the corresponding colony ones in all cases (Table 1 and further discussed in Table 3). Mosses, in turn, presented similar levels when compared to soil, with one notable exception for mosses, Ferraz, located next to the Brazilian Scientific Station (EACF). This could be due to several reasons: fossil fuel burning (a notable source of $\mathrm{Hg}$ ), less yearround ice cover (meaning more exposed vegetation surface and less $\mathrm{Hg}$ trapped within snow and ice) and also the fire from February 2012, which consumed the whole station core and roughly $70 \%$ of the total facilities, releasing significant amounts of organic and inorganic contaminants (Colabuono et al., 2015; Guerra et al., 2013).

Lichens presented overall levels roughly with a two-fold increase, but still in the same order of magnitude as mosses, except the sampling sites close to research stations (Ferraz and Stenhouse) confirming Ferraz as a $\mathrm{Hg}$ source due to prevailing westerly and southwesterly winds (Wielbinska and Skrzypczak, 1988). This role had been previously proposed by another study (dos Santos et al., 2006). Another local source is due to present or ancient volcanic activity. Deception Island is an active volcano (Goyanes et al., 2014) and Penguin Island, where the Sterna vittata samples were collected, is an ancient volcano crater, with samples from these sites clearly distinguished from the rest, concerning lichens, but not necessarily mosses and soil. Particularly for Deception Island, literature indicates volcanic activity as the main $\mathrm{Hg}$ source, but also exceptional conditions for $\mathrm{Hg}$ methylation and low demethylation processes, increasing its bioavailability for aquatic organisms (Mão de Ferro et al., 2014). Such conditions may also affect $\mathrm{Hg}$ levels in vegetation as well via marine spray for instance. This marine spray is also reported to have significant influence in the geochemical composition of Antarctic soils (Malandrino et al., 2009).

Regarding $\mathrm{Cd}$ in a general way, soil concentrations were comparatively higher than mosses', followed by lichens highlighting lesser mobility when compared to $\mathrm{Hg}$, likely due to 
lesser atmospheric deposition and re-suspension among other reasons. Moreover, Cd concentrations remained under the limit of detection in all but one of the soil control sites suggesting the input of this element starkly linked to the bird colonies. Overall results seem in agreement with excreta and soil data (Celis et al., 2015; Espejo et al., 2014). The fact that most of the times colony soil samples present higher values when compared to excreta emphasizes the role of the former as a sink of trace elements. The input notably surpasses the eventual remobilisation processes when the respective control sites present much lower concentrations. This is apparently the case for most of the studied variables, as further discussed.

\section{Correlations}

Spearman correlation results are presented in Table 2. PCA is presented as supplementary material (Fig. S1).

$\mathrm{Hg}$ in lichens presents no significant correlation in control sites, probably due to the fact that they lack a true root system and absorb contaminants directly from the atmosphere (Park et al., 2010; Villeneuve et al., 1988; Yogui and Sericano, 2008), with no interaction with the elements present in the substrata (Kappen, 2000; Olech, 1994). However, in colony samples, $\mathrm{Hg}$ presented significant correlations $\left(+\mathrm{Pb},+\mathrm{Se},-\mathrm{Zn},-\delta^{15} \mathrm{~N},-\% \mathrm{~N}\right)$ indicating not only the resuspension/re-emission (see Jiskra et al., 2015) from the colonies as a common source for $\mathrm{Hg}$ and these other trace elements but also with nitrogen. In a previous work (Cipro et al., 2011), negative correlation with $\delta^{15} \mathrm{~N}$ was associated with more volatile or re-suspended contaminants whereas positive correlation was associated with the less volatile ones and/or more watersoluble as the ammonium. This is due to the fact that the kinetic fractionations during the decomposition of deposited urea and uric acid lead to the formation of in starkly ${ }^{15} \mathrm{~N}$-depleted highly volatile ammonia whereas the remaining ammonium, much less volatile, is conversely ${ }^{15} \mathrm{~N}$-enriched (Heaton, 1986). Therefore it results that plants around the excrement zone are more exposed to ${ }^{15} \mathrm{~N}$-enriched inorganic nitrogen whereas upland sites are more exposed to ${ }^{15} \mathrm{~N}$ depleted nitrogen (Cipro et al., 2011). Consequently, animal-derived nitrogen uptake is associated with large $\delta^{15} \mathrm{~N}$ ranges, with typical values ranging between 6 and 26\%o (e.g. Cipro et al., 2011; Cocks et al., 1998; Erskine et al., 1998; Mizutani and Wada, 1988). So, it could be inferred that the ammonia source correlates to the $\mathrm{Hg}$ source. $\mathrm{Cd}$ in lichens, on the other hand, is clearly related to the organic matter content, since it correlates to $\% \mathrm{~N}$ in both control and colony sites and with $\delta^{15} \mathrm{~N}$ in colony sites as well. 
Lower $\delta^{13} \mathrm{C}$, in turn, are related to moister habitats and marine influence, as well as high $\delta^{15} \mathrm{~N}$ (Cipro et al., 2011; Lee et al., 2009), which comes in agreement with our results both inter and intra-groups: mosses presented, in a general way, lower $\delta^{13} \mathrm{C}$ than lichens and coastal locations presented lower $\delta^{13} \mathrm{C}$ than the more inland ones for both mosses and lichens, in a much analogous way to what was previously described in literature, both qualitatively and quantitatively (Huiskes et al., 2006).

Taking mosses into consideration, a significant positive correlation with $\mathrm{Pb}$ could indicate a common source for control sites. The same conclusion could be taken in regard to $\mathrm{Co}, \mathrm{Cr}$ and $\mathrm{Ni}$ presenting significant negative correlations with $\mathrm{Hg}$ in colony sites: these trace elements would most likely come from natural sources rather than a colony input. This is reinforced by the fact that these three elements presented significant negative correlations with an indicator of organic matter $(\% \mathrm{C}$ and/or $\% \mathrm{~N}) . \mathrm{Cd}$, in turn, presented significant positive correlation with $\% \mathrm{~N}$ and negative with $\% \mathrm{C}$ in colony sites, which apparently points in two opposite directions, but could be related to the ornithogenic soil composition and decaying processes as previously described (see Emslie et al., 2013).

In respect to soil samples, the influence of colonies in $\mathrm{Hg}$ concentrations has been reported by several studies (Choy et al., 2010; Huang et al., 2014; Nie et al., 2012) and confirmed by significant positive correlations for both $\% \mathrm{C}$ and $\% \mathrm{~N}$. The same pattern is repeated for $\mathrm{Cd}$ as well as the same significant positive correlation with $\mathrm{As}$, Se and $\mathrm{Zn}$ detected in mosses colony samples as well.

The results of the PCA (see supplementary material Fig. S1) corroborate the previous discussion on correlations found for each of the subset of samples. However, some interesting trends appear when the dataset is taken as a whole since opposing behaviours have been detected for the same variables in different matrixes. Considering all matrixes, $\% \mathrm{C}$ and $\delta^{13} \mathrm{C}$ were positively correlated with each other and negatively correlated to most other trace elements, likely due to the previously discussed decaying processes of organic matter. Conversely, $\% \mathrm{~N}$ and $\mathrm{Hg}$ were positively correlated with each other (due to the influence of organic matter previously discussed) and negatively correlated with some trace elements, particularly $\mathrm{Mn}$ and $\mathrm{Pb}$. This is likely due to the natural origin of these trace elements, contrary to $\mathrm{Hg}$. All these behaviours are repeated for the Colony subset when all matrixes are taken. However, when only Control samples are taken, \% $\mathrm{C}$ and $\mathrm{Hg}$ were clearly associated and opposed to almost all other variables with two clear exceptions: $\% \mathrm{~N}$ and $\delta^{13} \mathrm{C}$. This is likely 
due to the differences in origin (natural/colony and atmospheric/bedrock) for these and the remaining variables.

\section{Factors influencing $\mathrm{Hg}$ and Cd concentrations}

In order to evaluate the relative importance of the categorical variables (main location, specific location, colony species and matrix species), GLM models were built and model selection was based upon AICc as previously explained.

Regarding $\mathrm{Hg}$, the most accurate model for lichen control samples presented $\delta^{13} \mathrm{C}$, $\delta^{15} \mathrm{~N}, \% \mathrm{~N}$, Specific Location and Matrix Species as factors $\left(\mathrm{w}_{\mathrm{i}}=0.51\right)$ and Specific Location and Matrix Species for colony samples $\left(\mathrm{w}_{\mathrm{i}}=0.33\right)$. For mosses, the most accurate model for control samples was composed of $\delta^{15} \mathrm{~N}, \% \mathrm{~N}$ and Specific Location $\left(\mathrm{w}_{\mathrm{i}}=0.31\right)$, whereas for colony samples it was composed of Specific Location, Colony Species and Matrix Species $\left(\mathrm{w}_{\mathrm{i}}=0.17\right)$. Finally, the most accurate model for soil control samples presented $\% \mathrm{~N}$ and Main Location as factors $\left(\mathrm{w}_{\mathrm{i}}=0.30\right)$ and Main Location and Colony Species for colony samples $\left(\mathrm{w}_{\mathrm{i}}=0.26\right)$.

Regarding Cd, the most accurate model for lichen control samples presented $\delta^{13} \mathrm{C}, \% \mathrm{C}$, Specific Location and Matrix Species as factors $\left(\mathrm{w}_{\mathrm{i}}=0.38\right)$ and $\delta^{13} \mathrm{C}, \delta^{15} \mathrm{~N}, \% \mathrm{~N}$, Main Location and Matrix Species for colony samples $\left(\mathrm{w}_{\mathrm{i}}=0.34\right)$. For mosses, the most accurate model for control samples was composed of $\delta^{13} \mathrm{C}$ and Matrix Species $\left(\mathrm{w}_{\mathrm{i}}=0.31\right)$, whereas for colony samples it was composed of $\delta^{15} \mathrm{~N}$, Specific Location, Colony Species and Matrix Species $\left(\mathrm{w}_{\mathrm{i}}=0.31\right)$. Finally, the most accurate model for soil control samples presented $\delta^{13} \mathrm{C}$ and Specific Location as factors, tied to $\% \mathrm{~N}$, Main Location and Specific Location $\left(\mathrm{w}_{\mathrm{i}}=0.50\right.$ each) and $\delta^{15} \mathrm{~N}$, Specific Location and Colony Species for colony samples $\left(\mathrm{w}_{\mathrm{i}}=0.56\right)$.

Thanks to the GLM, it is possible to notice some patterns. Firstly, the factors are quite similar between $\mathrm{Hg}$ and $\mathrm{Cd}$, especially for colony samples of mosses and soil. Moreover, for colony samples, there seems to be some effect of the matrix species but the colony species seems to be more present and in models with higher Akaike weights, suggesting colony species as the categorical variable with the most prominent role in explaining both $\mathrm{Hg}$ and $\mathrm{Cd}$ concentrations. This is likely due to different feeding ecology among species, and therefore, to $\mathrm{Hg}$ levels in bird droppings, but also to some variables that could not yet have been explored, such as colony size and/or density, directly linked to the local total $\mathrm{Hg}$ input. Moreover, moult 
may also play a major role, since they might constitute an important pathway of $\mathrm{Hg}$ excretion (Carravieri et al., 2014) towards soils.

\section{Control sites versus colony sites}

Firstly, some Tukey HSD/ANOVA tests were performed in order to understand whether some collection sites with apparently abnormal concentrations were really not grouped with their counterparts, confirming some hypothesised local source other than the colonies.

In respect to $\mathrm{Hg}$, in lichens, the colony samples from $S$. vittata $(\mathrm{p}<0.001)$ in Penguin Island (an ancient volcano crater) and from Larus dominicanus ( $\mathrm{p}=0.01)$ in Stenhouse Point (subject to winds previously passing by 3 close research stations) were set apart of all the other lichen samples. For mosses, the control sample from Ferraz (the Brazilian research station) was set apart all of the other samples $(\mathrm{p}<0.001)$. Finally, for soil samples, Pygoscelis adeliae from Penguin Island $(\mathrm{p}<0.001)$ and Pygoscelis antarcticus from Half Moon $(\mathrm{p}<0.001)$ can be set apart of all the other soil samples. Regarding $\mathrm{Cd}$, there was no particular separation other than lichens from $P$. antarcticus from Half Moon $(\mathrm{p}<0.001)$. Taking all of that into account, it is possible to infer three local $\mathrm{Hg}$ sources: research stations in King George Island, the ancient volcano crater in Penguin Island and another source of both $\mathrm{Hg}$ and $\mathrm{Cd}$ in Half Moon Island yet to be identified. The Island is home for several reproducing birds and hauling-out pinniped species during the summer, an important ship traffic and tourist site, paleovolcanic activity and also has a summer-only research station, therefore a lot of potential sources. Curiously, even human disturbance might play a role in trace element concentrations in penguins, even if indirectly (Barbosa et al., 2013).

Following, the results for the t-tests of colony sites compared to the closest control site are presented in Table 3.

Results show some interesting patterns. Lichens presented comparatively less difference between colony and control sites than mosses, which presented comparatively less difference between colony and control sites than soil samples. Lichens presented markedly differences in $\delta^{13} \mathrm{C}$ likely due to the previously discussed influence of moisture and marine influence and also $\%$ N. For this latter, it is noticeable that in most of the cases when this variable was significantly different between colony and control sites, it was mostly with higher trophic level species, such as Macronectes giganteus, that normally form smaller and less dense colonies 
when compared to penguins or shags for instance. Mosses, in turn, presented significant difference for most of the stable isotopes, $\% \mathrm{C}$ and $\% \mathrm{~N}$, and moreover, among trace elements, particularly for $\mathrm{Hg}$, likely due to the influence of runoff water, as they are more moisturedependent than lichens, that occur mostly in higher, more exposed spots in this area (Kim et al., 2007). This has already been suggested by other studies for organic contaminants (Cipro et al., 2011; Cunha et al., 2015).

Finally, soil samples presented differences between control and colony sites for almost all of the cases, with two notable exceptions: $\mathrm{Cd}$, which remained under the method detection limit in all control sites, confirming the fact that the input of this trace element in this matrix is closely related to bird colonies (i.e. the difference exists but cannot be tested due to the lack of valid numbers); and $\delta^{15} \mathrm{~N}$, which presented significant difference only in Phalacrocorax atriceps colony sites, all of them. From field experience (authors personal observations), the colonies of this species presented the thickest layer of ornithogenic soil, in most cases located in higher and drier spots when compared to penguins. These locations would favour the accumulation of guano and impair the lixiviation of the guano-derived ammonium, enriching the $\delta^{15} \mathrm{~N}$ signature as previously discussed.

\section{A mass balance perspective}

At first, the fact that terrestrial ecosystems adjacent to seabird colonies present significantly higher concentrations when compared to locations further from such colonies does not necessarily mean that the referred ecosystem becomes enriched in pollutants as a whole: it could be a mere matter of remobilisation from one compartment to another. It does mean though that there is local enrichment and that assumption in no way excludes the previous hypothesis.

In order to verify the role of colonies as a source from a mass balance perspective, one must recur to the literature. It is estimated that global seabirds inputs of $\mathrm{N}$ and $\mathrm{P}$ are respectively of $591 \mathrm{Gg} \mathrm{y}^{-1}$ and $99 \mathrm{Gg} \mathrm{y}^{-1}$, with the Antarctic and Southern Ocean coasts receiving the highest amounts, roughly $80 \%$ whereas these areas $26 \%$ of the global seabird population (Otero et al., 2018). Moreover, various authors (Ellis et al., 2006; Lorrain et al., 2017; Otero et al., 2015; Sutton et al., 2013) suggested that seabird colonies represent a positive geochemical anomaly (i.e., above background values) regarding the concentrations of $\mathrm{N}$ and $\mathrm{P}$ present in soils, sediments, and water, hence the term ornithoeutrophication (Otero et al., 2018). It is, therefore, 
reasonable to assume that seabird colonies enrich their ecosystems as a whole, in a mass balance perspective. Given that previous literature indicates that seabird faeces contain not only organic matter, but various of the concerned trace elements in the present work (Celis et al., 2015, 2014; Espejo et al., 2014; Finger et al., 2017), one can assume that the same affirmation made for organic matter is also valid for trace elements. To corroborate this assumption, literature brings also positive inputs for some trace elements in the Southern Ocean, for instance $\mathrm{Hg}$ (Cossa et al., 2011).

Taking into account the estimates for seabird excretion, the composition of excreta and colony size, it would be possible to estimate the net influx of some trace elements in a given colony or set of colonies. Cross-checking the literature for available data that could fit our sampling, a common case appeared: the Chinstrap Penguin (Pygoscelis antarcticus). Its total and breeding population are estimated at 12,800,000 and 8,000,000 individuals that would input 55.551 Gg N y ${ }^{-1}$ and $9.529 \mathrm{Gg} \mathrm{P} \mathrm{y}^{-1}$ (Otero et al., 2018), resulting in an individual average of 4.339 $\mathrm{Kg} \mathrm{N} \mathrm{y}^{-1}$ and $0.744 \mathrm{Kg} \mathrm{P} \mathrm{y}^{-1}$. The total $\mathrm{N}$ for excrements in this area averages $2.89 \% \mathrm{dw}$ (Zhu et al., 2009). Using $\mathrm{N}$ as a proxy, the trace elements data for faeces from the closest site to Admiralty Bay (Narebski Point) in literature (Espejo et al., 2014) and the breeding population in Admiralty Bay being in average 1436 pairs (Petry et al., 2015), resulting in 4595 individuals (keeping the proportion between total and breeding individuals from Otero et al., 2018), one would have a total annual input of approximately $904 \mathrm{~g}$ of $\mathrm{Pb}, 2160 \mathrm{~g}$ of Cd, $460 \mathrm{~g}$ of As, 179 $\mathrm{Kg}$ of $\mathrm{Cu}$ and $157 \mathrm{Kg}$ of $\mathrm{Zn}$, only from the $P$. antarcticus individuals within the ecosystem of Admiralty Bay, King George Island.

Unfortunately, to the best of our knowledge there are no estimates of biomass for lichens and mosses in none of the areas comprehended in this study. Therefore, no direct estimation on the inventories of trace elements in these compartments can be performed nor the transfer from the colonies to these organisms. Estimation for soil inventories (Hawke, 2003; Hawke et al., 1999) is not possible either because of the need for core sampling due to previous colonies, percolation and so on (Liu et al., 2006; Tatur et al., 1997).

However, there is a mean estimate of $62.13 \mathrm{~g} \mathrm{~m}^{-2}$ dry mass for Usnea lichen biomass from a volcanic mesa (Bohuslavová et al., 2012) a densely covered area that could be used as a starting point to estimate colony sites. The total $P$. antarcticus colony area in King George Island is estimated to be 0.14 ha (Petry et al., 2015) and $10 \%$ of the cover is estimated to be Usnea spp. (Kim et al., 2007) in another location in King George Island. A conservative estimation of lichen biomass would consider a 50m ring around these colonies, since we 
assumed a 50m distance to the colony to classify a sampling site as such. Moreover, since colonies are often ashore, we will consider only half of the resulting surface, since the other half would fall over the water. Yet conservatively we will consider only one colony for this whole 0.14 ha area, therefore a circle of $21.11 \mathrm{~m}$ radius. This will result in a $7243 \mathrm{~m}^{2}$ area of Usnea under the influence of the colony. Taking all previous data into account, this would result in approximately $45 \mathrm{Kg}$ of Usnea in the whole surface under the influence of $P$. antarcticus. With the data from the present work for lichens (unfortunately the only site available was in Half Moon and with Ramalina terebrata) and $P$. antarcticus averages, one could deduce an inventory of $27 \mathrm{mg} \mathrm{As}, 20 \mathrm{mg} \mathrm{Cd}, 10 \mathrm{mg} \mathrm{Hg}$ and $2 \mathrm{mg} \mathrm{Pb}$ only in the lichen compartment under the influence of $P$. antarcticus. Inventories for mosses will likely overcome those for lichens since mosses presented higher concentrations in a general way and also, from field experience, they should present considerably higher biomass. The same reasoning can be repeated concerning soil samples, which should represent the overall highest inventory among the matrixes sampled in this study.

\section{Conclusions}

The use of different matrixes in several different locations allowed the drawing of broader conclusions that otherwise would not be possible. In most cases, soil seems to be the best indicator to assess bird colonies as trace elements sources in these particular ecosystems as this matrix presented comparatively more differences between control and colony sites than vegetation. Bird colonies are clearly local sources of organic matter, $\mathrm{Cd}$ and $\mathrm{Hg}$ and likely of some other trace elements (As, Se and $\mathrm{Zn}$ ). Conversely, $\mathrm{Co}, \mathrm{Cr}, \mathrm{Ni}$ and $\mathrm{Pb}$ come most likely from other sources than the colonies themselves, since when differences between colony and control sites were detected, in most cases the control ones presented higher concentrations. Both natural and anthropogenic sources for these elements have been reported previously (e.g. Bollhöfer and Rosman, 2001) and further research would be needed to separate them. In a general way, isotopes were more useful for vegetation (particularly mosses) as indicators of colonies influence whereas elemental composition was more useful for soil samples. $\mathrm{Local} \mathrm{Hg}$ sources could be inferred from high levels in control sites and also from location and wind patterns. The mass balance approach provided fruitful insight, however more accurate field measurements of biomass are needed to refine its results and conclusions. Finally further studies could assess the influence of population status and dynamics on the results hereby found. 


\section{Acknowledgements}

The authors would like to acknowledge the financing organisms in the University of La Rochelle: CPER (Contrat de Plan État-Région) and FASEP (Fonds d'étude et d'aide au secteur privé). C.V.Z. Cipro received scholarships from FAPESP (São Paulo Research Foundation, Brazil. Grant \#2014/15989-0 and grant \#2015/07209-8). M. V. Petry received funding from INCT-APA (Instituto Nacional de Ciência e Tecnologia Antártico de Pesquisas Ambientais) (CNPq Process n574018/2008-5), FAPERJ (E-26/170.023/2008) and was supported by the SECIRM, MMA and MCTI. The IUF (Institut Universitaire de France) is acknowledged for its support to PB as a senior member. C. Churlaud and M. Brault-Favrou from the "Plateforme Analyses Elémentaires" of LIENSs are to be thanked for their assistance in all trace elements analyses. G. Guillou and B. Lebreton from the "Plateforme Analyses Isotopiques" of LIENSs are also to be thanked for their assistance during SIA analyses. Finally, many thanks are dedicated to everyone involved in the fieldwork.

\section{References}

Anderson, W.B., Polis, G. a., 1999. Nutrient fluxes from water to land: seabirds affect plant nutrient status on Gulf of California islands. Oecologia 118, 324-332. doi:10.1007/s004420050733

Barbosa, A., De Mas, E., Benzal, J., Diaz, J.I., Motas, M., Jerez, S., Pertierra, L., Benayas, J., Justel, A., Lauzurica, P., Garcia-Peña, F.J., Serrano, T., 2013. Pollution and physiological variability in gentoo penguins at two rookeries with different levels of human visitation. Antarct. Sci. 25, 329-338. doi:10.1017/S0954102012000739

Bettinelli, M., Beone, G.M., Spezia, S., Baffi, C., 2000. Determination of heavy metals in soils and sediments by microwave-assisted digestion and inductively coupled plasma optical emission spectrometry analysis. Anal. Chim. Acta 424, 289-296. doi:10.1016/S0003-2670(00)01123-5

Blais, J.M., Kimpe, L.E., Mcmahon, D., Keatley, B.E., Mallory, M.L., Douglas, M.S. V, Smol, J.P., 2005. Arctic Seabirds Transport Marine-Derived Contaminants. Science (80-. ). 309, 445. doi:10.1126/science. 1112658

Blais, J.M., Macdonald, R.W., Mackay, D., Webster, E., Harvey, C., Smol, J.P., 2007. 
Biologically Mediated Transport of Contaminants to Aquatic Systems Critical Review Biologically Mediated Transport of Contaminants to Aquatic Systems 41, 1075-1084. doi:10.1021/es061314a

Blévin, P., Carravieri, A., Jaeger, A., Chastel, O., Bustamante, P., Cherel, Y., 2013. Wide Range of Mercury Contamination in Chicks of Southern Ocean Seabirds. PLoS One 8, e54508. doi:10.1371/journal.pone.0054508

Bohuslavová, O., Šmilauer, P., Elster, J., 2012. Usnea lichen community biomass estimation on volcanic mesas, James Ross Island, Antarctica. Polar Biol. 35, 1563-1572. doi:10.1007/s00300-012-1197-0

Bollhöfer, A., Rosman, K.J.., 2001. Isotopic source signatures for atmospheric lead: the Northern Hemisphere. Geochim. Cosmochim. Acta 65, 1727-1740. doi:10.1016/S00167037(00)00630-X

Brasso, R.L., Polito, M.J., Lynch, H.J., Naveen, R., Emslie, S.D., 2012. Penguin eggshell membranes reflect homogeneity of mercury in the marine food web surrounding the Antarctic Peninsula. Sci. Total Environ. 439, 165-71. doi:10.1016/j.scitotenv.2012.09.028

Burnham, K.P., Anderson, D.R., 2002. Model Selection and Multimodel Inference, 2nd ed. Springer.

Carravieri, A., Cherel, Y., Blévin, P., Brault-Favrou, M., Chastel, O., Bustamante, P., 2014. Mercury exposure in a large subantarctic avian community. Environ. Pollut. 190C, 5157. doi:10.1016/j.envpol.2014.03.017

Celis, J.E., Barra, R., Espejo, W., González-Acuña, D., Jara, S., 2015. Trace Element Concentrations in Biotic Matrices of Gentoo Penguins (Pygoscelis Papua) and Coastal Soils from Different Locations of the Antarctic Peninsula. Water. Air. Soil Pollut. 226. doi:10.1007/s11270-014-2266-5

Celis, J.E., Espejo, W., González-Acuña, D., Jara, S., Barra, R., 2014. Assessment of trace metals and porphyrins in excreta of Humboldt penguins (Spheniscus humboldti) in different locations of the northern coast of Chile. Environ. Monit. Assess. 186, 18151824. doi:10.1007/s10661-013-3495-6

Chouvelon, T., Spitz, J., Caurant, F., Mèndez-Fernandez, P., Autier, J., Lassus-Débat, a., Chappuis, a., Bustamante, P., 2012. Enhanced bioaccumulation of mercury in deep-sea 
fauna from the Bay of Biscay (north-east Atlantic) in relation to trophic positions identified by analysis of carbon and nitrogen stable isotopes. Deep Sea Res. Part I Oceanogr. Res. Pap. 65, 113-124. doi:10.1016/j.dsr.2012.02.010

Choy, E.S., Gauthier, M., Mallory, M.L., Smol, J.P., Douglas, M.S. V, Lean, D., Blais, J.M., 2010. An isotopic investigation of mercury accumulation in terrestrial food webs adjacent to an Arctic seabird colony. Sci. Total Environ. 408, 1858-67. doi:10.1016/j.scitotenv.2010.01.014

Cipro, C.V.Z., Cherel, Y., Bocher, P., Caurant, F., Miramand, P., Bustamante, P., 2018. Trace elements in invertebrates and fish from Kerguelen waters, southern Indian Ocean. Polar Biol. 41, 175-191. doi:10.1007/s00300-017-2180-6

Cipro, C.V.Z., Montone, R.C., Bustamante, P., 2017. Mercury in the ecosystem of Admiralty Bay, King George Island, Antarctica: Occurrence and trophic distribution. Mar. Pollut. Bull. 114, 564-570. doi:10.1016/j.marpolbul.2016.09.024

Cipro, C.V.Z., Yogui, G.T., Bustamante, P., Taniguchi, S., Sericano, J.L., Montone, R.C., 2011. Organic pollutants and their correlation with stable isotopes in vegetation from King George Island, Antarctica. Chemosphere 85, 393-8. doi:10.1016/j.chemosphere.2011.07.047

Cocks, M.P., Balfour, D. a., Stock, W.D., 1998. On the uptake of ornithogenic products by plants on the inland mountains of Dronning Maud Land, Antarctica, using stable isotopes. Polar Biol. 20, 107-111. doi:10.1007/s003000050283

Colabuono, F.I., Taniguchi, S., Cipro, C.V.Z., da Silva, J., Bícego, M.C., Montone, R.C., 2015. Persistent organic pollutants and polycyclic aromatic hydrocarbons in mosses after fire at the Brazilian Antarctic Station. Mar. Pollut. Bull. 93, 266-269. doi:10.1016/j.marpolbul.2015.01.018

Coquery, M., Azemard, S., Mora, S., 2001. The analytical performance study for the Medpol region: determination of trace elements and methylmercury in estuarine sediment sample.

Cossa, D., Heimbürger, L.-E., Lannuzel, D., Rintoul, S.R., Butler, E.C.V., Bowie, A.R., Averty, B., Watson, R.J., Remenyi, T., 2011. Mercury in the Southern Ocean. Geochim. Cosmochim. Acta 75, 4037-4052. doi:10.1016/j.gca.2011.05.001

Cunha, L.S.T., Costa, E.S., Pessoa, A.R.L., Souza, J.S., Padilha, J.A., Torres, F.B.M., Torres, 
J.P.M., 2015. Do Penguin Concentrate Persistent Toxic Substances in Their Breeding Colonies ? Organohalogen Compd. 77, 672-676.

dos Santos, I.R., Silva-Filho, E.V., Schaefer, C., Sella, S.M., Silva, C.A., Gomes, V., Passos, M.J. de A.C.R., Van Ngan, P., 2006. Baseline mercury and zinc concentrations in terrestrial and coastal organisms of Admiralty Bay, Antarctica. Environ. Pollut. 140, 304-311. doi:10.1016/j.envpol.2005.07.007

Ellis, J.C., Fariña, J.M., Witman, J.D., 2006. Nutrient transfer from sea to land: The case of gulls and cormorants in the Gulf of Maine. J. Anim. Ecol. 75, 565-574. doi:10.1111/j.1365-2656.2006.01077.x

Emslie, S.D., Polito, M.J., Brasso, R., Patterson, W.P., Sun, L., 2014. Ornithogenic soils and the paleoecology of pygoscelid penguins in antarctica. Quat. Int. 352, 4-15. doi:10.1016/j.quaint.2014.07.031

Emslie, S.D., Polito, M.J., Patterson, W.P., 2013. Stable isotope analysis of ancient and modern gentoo penguin egg membrane and the krill surplus hypothesis in Antarctica. Antarct. Sci. Antarct. Sci. Ltd 25, 213-218. doi:10.1017/S0954102012000740

Erskine, P.D., Bergstrom, D.M., Schmidt, S., Stewart, G.R., Tweedie, C.E., Shaw, J.D., 1998. Subantarctic Macquarie Island - a model ecosystem for studying animal-derived nitrogen sources using $15 \mathrm{~N}$ natural abundance. Oecologia 117, 187-193. doi:10.1007/s004420050647

Espejo, W., Celis, J.E., González-Acuña, D., Jara, S., Barra, R., 2014. Concentration of trace metals in excrements of two species of penguins from different locations of the Antarctic Peninsula. Polar Biol. 37, 675-683. doi:10.1007/s00300-014-1468-z

Finger, A., Lavers, J.L., Dann, P., Kowalczyk, N.D., Scarpaci, C., Nugegoda, D., Orbell, J.D., 2017. Metals and metalloids in Little Penguin (Eudyptula minor) prey, blood and faeces. Environ. Pollut. 223, 567-574. doi:10.1016/j.envpol.2017.01.059

Garcia, L. V, Marañón, T., Ojeda, F., Clemente, L., Redondo, R., 2002. Seagull Influence on Soil Properties, Chenopod Shrub Distribution, and Leaf Nutrient Status in Semi-Arid Mediterranean Islands. OIKOS 98, 75-86.

Goyanes, G., Vieira, G., Caselli, A., Cardoso, M., Marmy, A., Santos, F., Bernardo, I., Hauck, C., 2014. Local influences of geothermal anomalies on permafrost distribution in an active volcanic island (Deception Island, Antarctica). Geomorphology 225, 57-68. 
doi:10.1016/j.geomorph.2014.04.010

Guerra, M.B.B., Neto, E.L., Prianti, M.T.A., Pereira-Filho, E.R., Schaefer, C.E.G.R., 2013. Post-fire study of the Brazilian Scientific Antarctic Station: Toxic element contamination and potential mobility on the surrounding environment. Microchem. J. 110, 21-27. doi:10.1016/j.microc.2013.01.007

Hawke, D.J., 2003. Cadmium distribution and inventories at a pre-Europenan seabird breeding site on agricultural land, Banks Peninsula, New Zealand. Aust. J. Soil Res. 41, $19-26$.

Hawke, D.J., Holdaway, R.N., Causer, J.E., Ogden, S., 1999. Soil indicators of pre-European seabird breeding in New Zealand at sites identified by predator deposits. Aust. J. Soil Res. 37, 103-114.

Heaton, T.H.E., 1986. Isotopic studies of nitrogen pollution in the hydrosphere and atmosphere: a review. Chem. Geol. 59, 87-102.

Hindell, M.A., Burton, H.R., 1988. Seasonal haul-out patterns of the southern elephant seal (Mirounga leonina L.) at Macquarie Island. J. Mamm. 69, 81-88.

Huang, T., Sun, L., Wang, Y., Chu, Z., Qin, X., Yang, L., 2014. Transport of nutrients and contaminants from ocean to island by emperor penguins from Amanda Bay, East Antarctic. Sci. Total Environ. 468-469, 578-583. doi:10.1016/j.scitotenv.2013.08.082

Huiskes, a. H.L., Boschker, H.T.S., Lud, D., Moerdijk-Poortvliet, T.C.W., 2006. Stable isotope ratios as a tool for assessing changes in carbon and nutrient sources in Antarctic terrestrial ecosystems. Plant Ecol. doi:10.1007/s11258-005-9032-0

Jiskra, M., Wiederhold, J.G., Skyllberg, U., Kronberg, R.M., Hajdas, I., Kretzschmar, R., 2015. Mercury Deposition and Re-emission Pathways in Boreal Forest Soils Investigated with Hg Isotope Signatures. Environ. Sci. Technol. 49, 7188-7196. doi:10.1021/acs.est.5b00742

Johnson, J.B., Omland, K.S., 2004. Model selection in ecology and evolution. Trends Ecol. Evol. 19, 101-8. doi:10.1016/j.tree.2003.10.013

Kappen, L., 2000. Some aspects of the great success of lichens in Antarctica. Antarct. Sci. 12, 314-324. doi:10.1017/S0954102000000377

Kim, J.H., Ahn, I.-Y., Lee, K.S., Chung, H., Choi, H.-G., 2007. Vegetation of Barton 
Peninsula in the neighbourhood of King Sejong Station (King George Island, maritime Antarctic). Polar Biol. 30, 903-916. doi:10.1007/s00300-006-0250-2

Lake, S.E., Burton, H.R., Hindell, M.A., 1997. Influence of time of day and month on Weddell seal haul-out patterns at the Vestfold Hills, Antarctica. Polar Biol. 18, 319-324. doi:10.1007/s003000050194

Lee, Y. Il, Lim, H.S., Yoon, H. Il, 2009. Carbon and nitrogen isotope composition of vegetation on King George Island, maritime Antarctic. Polar Biol. 32, 1607-1615. doi:10.1007/s00300-009-0659-5

Lim, H.S., Han, M.J., Seo, D.C., Kim, J.H., Lee, J.I., Park, H., Hur, J.-S., Cheong, Y.H., Heo, J.S., Yoon, H. Il, Cho, J.-S., 2009. Heavy Metal Concentrations in the Fruticose Lichen Usnea aurantiacoatra from King George Island, South Shetland Islands, West Antarctica. J. Korean Soc. Appl. Biol. Chem. 52, 503-508. doi:10.3839/jksabc.2009.086

Liu, X., Li, H., Sun, L., Yin, X., Zhao, S., Wang, Y., 2006. $\delta^{13} \mathrm{C}$ and $\delta^{15} \mathrm{~N}$ in the ornithogenic sediments from the Antarctic maritime as palaeoecological proxies during the past 2000 yr. Earth Planet. Sci. Lett. 243, 424-438. doi:10.1016/j.eps1.2006.01.018

Lorrain, A., Houlbrèque, F., Benzoni, F., Barjon, L., Tremblay-Boyer, L., Menkes, C., Gillikin, D.P., Payri, C., Jourdan, H., Boussarie, G., Verheyden, A., Vidal, E., 2017. Seabirds supply nitrogen to reef-building corals on remote Pacific islets. Sci. Rep. 7, 111. doi:10.1038/s41598-017-03781-y

Lucia, M., Strøm, H., Bustamante, P., Gabrielsen, G.W., 2016. Trace Element Concentrations in Relation to the Trophic Behaviour of Endangered Ivory Gulls (Pagophila eburnea) During Their Stay at a Breeding Site in Svalbard. Arch. Environ. Contam. Toxicol. 71, 518-529. doi:10.1007/s00244-016-0320-6

Malandrino, M., Abollino, O., Buoso, S., Casalino, C.E., Gasparon, M., Giacomino, A., La Gioia, C., Mentasti, E., 2009. Geochemical characterisation of Antarctic soils and lacustrine sediments from Terra Nova Bay. Microchem. J. 92, 21-31. doi:10.1016/j.microc.2008.09.003

Mão de Ferro, A., Mota, A.M., Canário, J., 2014. Pathways and speciation of mercury in the environmental compartments of Deception Island, Antarctica. Chemosphere 95, 227-33. doi:10.1016/j.chemosphere.2013.08.081

Mão de Ferro, A., Mota, A.M., Canário, J., 2013. Sources and transport of As, $\mathrm{Cu}, \mathrm{Cd}$ and $\mathrm{Pb}$ 
in the environmental compartments of Deception Island, Antarctica. Mar. Pollut. Bull. 77, 341-348. doi:10.1016/j.marpolbul.2013.08.037

Mizutani, H., Wada, E., 1988. Nitrogen and carbon isotope ratios in seabird rookeries and their ecological implications. Ecology 69, 340-349.

Negoita, T.G., Covaci, A., Gheorghe, A., Schepens, P., 2003. Distribution of polychlorinated biphenyls (PCBs) and organochlorine pesticides in soils from the East Antarctic coast. J. Environ. Monit. 5, 281-286. doi:10.1039/b300555k

Nie, Y., Liu, X., Sun, L., Emslie, S.D., 2012. Effect of penguin and seal excrement on mercury distribution in sediments from the Ross Sea region, East Antarctica. Sci. Total Environ. 433, 132-40. doi:10.1016/j.scitotenv.2012.06.022

Olech, M., 1994. Lichenological assessment of the Cape Lions Rump , King George Island, South Shetland Islands ; a baseline for monitoring biological changes. Polish Polar Res. $15,111-130$.

Olech, M., Kwiatek, W.M., Dutkiewicz, E.M., 1998. Lead Pollution in the Antarctic Region. X-Ray Spectrom. 27, 232-235. doi:10.1002/(SICI)10974539(199807/08)27:4<232::AID-XRS291>3.0.CO;2-U

Otero, X.L., De La Peña-Lastra, S., Pérez-Alberti, A., Ferreira, T.O., Huerta-Diaz, M.A., 2018. Seabird colonies as important global drivers in the nitrogen and phosphorus cycles. Nat. Commun. 9, 246. doi:10.1038/s41467-017-02446-8

Otero, X.L., Tejada, O., Martín-Pastor, M., De La Peña, S., Ferreira, T.O., Pérez-Alberti, A., 2015. Phosphorus in seagull colonies and the effect on the habitats. The case of yellowlegged gulls (Larus michahellis) in the Atlantic Islands National Park (Galicia-NW Spain). Sci. Total Environ. 532, 383-397. doi:10.1016/j.scitotenv.2015.06.013

Outridge, P.M., Goodsite, M.E., Bennike, O., Rausch, N., Shotyk, W., 2016. Seabird transfer of nutrients and trace elements from the north water polynya to land during the midholocene warm period, carey islands, northwest Greenland. Arctic 69, 253-265. doi:10.14430/arctic4577

Park, H., Lee, S.-H., Kim, M., Kim, J.-H., Lim, H.S., 2010. Polychlorinated biphenyl congeners in soils and lichens from King George Island, South Shetland Islands, Antarctica. Antarct. Sci. 22, 31. doi:10.1017/S0954102009990472

Petry, M.V., Valls, F.C.L., Petersen, E.D.S., Krüger, L., Piuco, R.D.C., dos Santos, C.R., 
2015. Breeding sites and population of seabirds on Admiralty Bay, King George Island, Antarctica. Polar Biol. doi:10.1007/s00300-015-1846-1

Prus, W., Fabiańska, M.J., Łabno, R., 2015. Geochemical markers of soil anthropogenic contaminants in polar scientific stations nearby (Antarctica, King George Island). Sci. Total Environ. 518-519, 266-279. doi:10.1016/j.scitotenv.2015.02.096

Roosens, L., Van Den Brink, N., Riddle, M., Blust, R., Neels, H., Covaci, A., 2007. Penguin colonies as secondary sources of contamination with persistent organic pollutants. J. Environ. Monit. 9, 822-5. doi:10.1039/b708103k

Rudolph, I., Chiang, G., Galbán-Malagón, C., Mendoza, R., Martinez, M., Gonzalez, C., Becerra, J., Servos, M.R., Munkittrick, K.R., Barra, R., 2016. Persistent organic pollutants and porphyrins biomarkers in penguin faeces from Kopaitic Island and Antarctic Peninsula. Sci. Total Environ. 573, 1390-1396. doi:10.1016/j.scitotenv.2016.07.091

Slip, D.J., Burton, H.R., 1999. Population status and seasonal haulout patterns of the southern elephant seal (Mirounga leonina) at Heard Island. Antarct. Sci. 11, 38-47. doi:10.1017/S0954102099000061

Smykla, J., Wołek, J., Barcikowski, A., 2007. Zonation of Vegetation Related to Penguin Rookeries on King George Island, Maritime Antarctic. Arctic, Antarct. Alp. Res. 39, 143-151. doi:10.1657/1523-043

Sutton, M.A., Reis, S., Riddick, S.N., Dragosits, U., Nemitz, E., Theobald, M.R., Tang, Y.S., Braban, C.F., Vieno, M., Dore, A.J., Mitchell, R.F., Wanless, S., Daunt, F., Fowler, D., Blackall, T.D., Milford, C., Flechard, C.R., Loubet, B., Massad, R., Cellier, P., Personne, E., Coheur, P.F., Clarisse, L., Van Damme, M., Ngadi, Y., Clerbaux, C., Skjoth, C.A., Geels, C., Hertel, O., Wichink Kruit, R.J., Pinder, R.W., Bash, J.O., Walker, J.T., Simpson, D., Horvath, L., Misselbrook, T.H., Bleeker, A., Dentener, F., de Vries, W., 2013. Towards a climate-dependent paradigm of ammonia emission and deposition. Philos. Trans. R. Soc. B Biol. Sci. 368, 20130166-20130166. doi:10.1098/rstb.2013.0166

Sysalová, J., Kučera, J., Fikrle, M., Drtinová, B., 2013. Determination of the total mercury in contaminated soils by direct solid sampling atomic absorption spectrometry using an AMA-254 device and radiochemical neutron activation analysis. Microchem. J. 110, 691-694. doi:10.1016/j.microc.2013.08.004 
Tan, S.W., Meiller, J.C., Mahaffey, K.R., 2009. The endocrine effects of mercury in humans and wildlife. Crit. Rev. Toxicol. 39, 228-269. doi:10.1080/10408440802233259

Tarcau, D., Cucu-Man, S., Boruvkova, J., Klanova, J., Covaci, A., 2013. Organochlorine pesticides in soil, moss and tree-bark from North-Eastern Romania. Sci. Total Environ. 456-457, 317-24. doi:10.1016/j.scitotenv.2013.03.103

Tatur, a., Myrcha, A., Niegodzisz, J., 1997. Formation of abandoned penguin rookery ecosystems in the maritime Antarctic. Polar Biol. 17, 405-417. doi:10.1007/s003000050135

Tsui, M.T.K., Wang, W.X., 2004. Uptake and Elimination Routes of Inorganic Mercury and Methylmercury in Daphnia magna. Environ. Sci. Technol. 38, 808-816. doi:10.1021/es034638x

Villeneuve, J.-P., Fogelqvist, E., Cattini, C., 1988. Lichens as bioindicators for atmospheric pollution by chlorinated hydrocarbons. Chemosphere 17, 399-403. doi:10.1016/00456535(88)90230-5

Wielbinska, D., Skrzypczak, E., 1988. Mean air temperatures at definite wind directions at Arctowski Station ,. Polish Polar Res. 9, 133-145.

Wojtuń, B., Kolon, K., Samecka-Cymerman, A., Jasion, M., Kempers, A.J., 2013. A survey of metal concentrations in higher plants, mosses, and lichens collected on King George Island in 1988. Polar Biol. 36, 913-918. doi:10.1007/s00300-013-1306-8

Yogui, G.T., Sericano, J.L., 2008. Polybrominated diphenyl ether flame retardants in lichens and mosses from King George Island, maritime Antarctica. Chemosphere 73, 1589-93. doi:10.1016/j.chemosphere.2008.08.035

Zheng, W., Xie, Z., Bergquist, B.A., 2015. Mercury Stable Isotopes in Ornithogenic Deposits As Tracers of Historical Cycling of Mercury in Ross Sea, Antarctica. Environ. Sci. Technol. 49, 7623-7632. doi:10.1021/acs.est.5b00523

Zhu, R., Liu, Y., Ma, E., Sun, J., Xu, H., Sun, L., 2009. Nutrient compositions and potential greenhouse gas production in penguin guano, ornithogenic soils and seal colony soils in coastal Antarctica. Antarct. Sci. 21, 427-438. doi:10.1017/S0954102009990204

Zvěřina, O., Coufalík, P., Brat, K., Červenka, R., Kuta, J., Mikeš, O., Komárek, J., 2016. Leaching of mercury from seal carcasses into Antarctic soils. Environ. Sci. Pollut. Res. 1-8. doi:10.1007/s11356-016-7879-3 
Zvěřina, O., Láska, K., Cervenka, R., Kuta, J., Coufalík, P., Komárek, J., 2014. Analysis of mercury and other heavy metals accumulated in lichen Usnea antarctica from James Ross Island, Antarctica. Environ. Monit. Assess. doi:10.1007/s10661-014-4068-Z 


\section{Table 1 - Mean results for trace elements concentration (in $\mu \mathrm{g} \mathrm{g}^{-1} \mathrm{dw}$ ), SIA (\%) and C and $\mathrm{N}$ content (\%) separated by location, colony species and matrix species}

\begin{tabular}{|c|c|c|c|c|c|c|c|c|c|c|c|c|c|c|c|c|}
\hline Main Location & Specific Location & Colony species & & Matrix Species & $\mathrm{n}$ & $\mathrm{Hg}$ & As & $\mathrm{Cd}$ & $\mathrm{Cu}$ & $\mathrm{Pb}$ & $\mathrm{Se}$ & $\mathrm{Zn}$ & $\delta^{13} \mathrm{C}$ & $\% \mathrm{C}$ & $\delta^{15} \mathrm{~N}$ & $\% \mathrm{~N}$ \\
\hline Deception Island & Deception Island & Control & | & Usnea antarctica & 3 & $0.232 \pm 0.072$ & $0.787 \pm 0.063$ & $0.068 \pm 0.024$ & $3.93 \pm 0.394$ & $0.325 \pm 0.020$ & $1.08 \pm 0.158$ & $13.1 \pm 2.24$ & $-22.175 \pm 3.69$ & $30.8 \pm 16.7$ & $-0.680 \pm 11.0$ & $2.13 \pm 1.22$ \\
\hline \multirow{2}{*}{ Half Moon } & \multirow{2}{*}{ Half Moon } & Control & 1 & Usnea aurantiaco-ater & 3 & $0.121 \pm 0.007$ & $0.178 \pm 0.027$ & $0.077 \pm 0.004$ & $2.66 \pm 0.533$ & $0.359 \pm 0.160$ & $1.57 \pm 0.358$ & $13.2 \pm 1.15$ & $-22.300 \pm 0.136$ & $41.7 \pm 0.264$ & $-5.730 \pm 0.947$ & $0.960 \pm 0.060$ \\
\hline & & Pygoscelis antarcticus & | & Ramalina terebrata & 3 & $0.223 \pm 0.020$ & $0.610 \pm 0.246$ & $0.445 \pm 0.244$ & $6.51 \pm 1.11$ & $0.045 \pm 0.011$ & $1.08 \pm 0.291$ & $16.0 \pm 8.00$ & $-23.940 \pm 0.840$ & $41.3 \pm 0.326$ & $-0.343 \pm 1.53$ & $2.21 \pm 0.466$ \\
\hline \multirow{10}{*}{ KGI } & Cape Vauréal & | Macronectes giganteus & 1 & Usnea antarctica & 3 & $0.190 \pm 0.065$ & $0.606 \pm 0.081$ & $0.111 \pm 0.026$ & $3.66 \pm 0.668$ & $0.230 \pm 0.018$ & $1.75 \pm 0.166$ & $15.2 \pm 5.48$ & $-21.960 \pm 0.701$ & $40.1 \pm 0.895$ & $-0.028 \pm 0.793$ & $0.668 \pm 0.02$ \\
\hline & Ferraz & Control &  & Usnea aurantiaco-ater & 3 & $0.307 \pm 0.083$ & $0.217 \pm 0.068$ & $0.021 \pm 0.002$ & $1.08 \pm 0.107$ & $0.766 \pm 0.122$ & $1.35 \pm 0.286$ & $7.16 \pm 1.09$ & $-20.750 \pm 0.125$ & $39.4 \pm 1.67$ & $-6.612 \pm 4.83$ & $0.341 \pm 0.04$ \\
\hline & Punta Hennequin & Catharacta $s p^{*}$ & 1 & Usnea antarctica & 3 & $0.079 \pm 0.001$ & $0.493 \pm 0.142$ & $0.052 \pm 0.022$ & $3.41 \pm 2.11$ & $0.115 \pm 0.038$ & $0.697 \pm 0.108$ & $18.2 \pm 4.40$ & $-23.175 \pm 0.403$ & $40.4 \pm 1.28$ & $0.250 \pm 1.35$ & $1.64 \pm 0.46$ \\
\hline & Stenhouse & Larus dominicanus* & | & Usnea antarctica & 3 & $0.526 \pm 0.160$ & $0.458 \pm 0.174$ & $0.017 \pm 0.004$ & $3.20 \pm 1.42$ & $0.802 \pm 0.257$ & $2.14 \pm 0.636$ & $10.5 \pm 3.28$ & $-22.395 \pm 0.864$ & $40.6 \pm 0.886$ & $-5.904 \pm 0.814$ & $0.526 \pm 0.06$ \\
\hline & \multirow{5}{*}{ Turret Point } & \multirow{3}{*}{ Control } & & Ramalina terebrata & 3 & $187 \pm 0.056$ & $0.455 \pm 0.120$ & $0.093 \pm 0.035$ & $4.71 \pm 0.788$ & $0.093 \pm 0.007$ & $0.942 \pm 0.134$ & $13.1 \pm 3.58$ & $-24.366 \pm 0.191$ & $40.5 \pm 0.774$ & $0.852 \pm 0.922$ & $1.67 \pm 0.161$ \\
\hline & & & & Usnea antarctica & 3 & $0.247 \pm 0.056$ & $0.302 \pm 0.064$ & $0.039 \pm 0.002$ & $3.41 \pm 0.846$ & $0.186 \pm 0.032$ & $1.01 \pm 0.283$ & $11.2 \pm 0.421$ & $-22.702 \pm 0.223$ & $40.3 \pm 1.21$ & $-3.155 \pm 0.555$ & $1.40 \pm 0.311$ \\
\hline & & & & Usnea aurantiaco-ater & 3 & $0.245 \pm 0.037$ & $0.453 \pm 0.083$ & $0.074 \pm 0.008$ & $3.39 \pm 0.458$ & $0.247 \pm 0.026$ & $1.20 \pm 0.277$ & $16.2 \pm 2.54$ & $-21.486 \pm 0.297$ & $39.9 \pm 0.520$ & $-5.875 \pm 0.599$ & $1.44 \pm 0.0$ \\
\hline & & Phalacrocorax atriceps & | & Ramalina terebrata & 3 & $0.123 \pm 0.021$ & $0.447 \pm 0.109$ & $0.027 \pm 0.002$ & $4.14 \pm 0.361$ & $0.058 \pm 0.005$ & $0.462 \pm-$ & $16.0 \pm 1.36$ & $-22.880 \pm 0.152$ & $38.5 \pm 0.522$ & $1.25 \pm 0.420$ & $1.50 \pm 0.20$ \\
\hline & & Pygoscelis adeliae & | & Usnea antarctica & 3 & $0.178 \pm 0.073$ & $0.527 \pm 0.022$ & $0.076 \pm 0.042$ & $11.2 \pm 7.10$ & $0.246 \pm 0.030$ & $1.48 \pm 0.218$ & $25.8 \pm 8.95$ & $-23.339 \pm 0.102$ & $38.4 \pm 1.39$ & $-1.594 \pm 1.83$ & $1.42 \pm 0.4$ \\
\hline & Yellow Point & Control & | & Usnea aurantiaco-ater & 1 & 0.154 & 2.40 & 0.105 & 7.97 & 1.75 & 1.64 & 18.1 & -22.066 & 39.0 & -1.949 & 1.34 \\
\hline \multirow{2}{*}{ Livingston } & \multirow{2}{*}{ Hannah Point } & Macronectes giganteus & & $\begin{array}{l}\text { Ramalina terebrata } \\
\text { Turgidiusculum complicatulum }\end{array}$ & 1 & $\begin{array}{c}0.179 \pm 0.062 \\
0.087\end{array}$ & $\begin{array}{c}0.691 \pm 0.071 \\
1.46\end{array}$ & $\begin{array}{c}0.087 \pm 0.034 \\
0.206\end{array}$ & $\begin{array}{c}5.65 \pm 0.543 \\
18.5\end{array}$ & $\begin{array}{c}0.121 \pm 0.007 \\
1.22\end{array}$ & $\begin{array}{c}1.37 \pm 0.806 \\
2.70\end{array}$ & $\begin{array}{c}15.3 \pm 1.77 \\
49.9\end{array}$ & $\begin{array}{l}-24.050 \pm 0.137 \\
-16.170\end{array}$ & $\begin{array}{c}42.1 \pm 3.29 \\
33.7\end{array}$ & $\begin{array}{c}-1.693 \pm 7.07 \\
9.78\end{array}$ & $\begin{array}{c}1.85 \pm 0.662 \\
4.18\end{array}$ \\
\hline & & Pygoscelis papua & 1 & Ramalina terebrata & 3 & $0.172 \pm 0.018$ & $0.462 \pm 0.060$ & $0.075 \pm 0.016$ & $5.52 \pm 0.369$ & $0.049 \pm 0.002$ & $1.47 \pm 0.243$ & $19.4 \pm 4.19$ & $-22.731 \pm 0.333$ & $40.2 \pm 1.04$ & $11.2 \pm 0.588$ & $2.02 \pm 0.071$ \\
\hline Nelson Island & Nelson Island & | Daption capense** & | & Usnea aurantiaco-ater & 3 & $0.213 \pm 0.022$ & $0.603 \pm 0.082$ & $0.104 \pm 0.018$ & $2.56 \pm 0.608$ & $0.102 \pm 0.013$ & $1.41 \pm 0.355$ & $13.2 \pm 1.91$ & $-22.837 \pm 0.525$ & $41.5 \pm 2.18$ & $5.04 \pm 6.30$ & $1.12 \pm 0.171$ \\
\hline \multirow{3}{*}{ Pengui } & \multirow{3}{*}{$P$} & Control & & Usnea aurantiaco-ater & 3 & $0.104 \pm 0.015$ & $0.218 \pm 0.028$ & $0.032 \pm 0.003$ & $4.08 \pm 1.53$ & $0.184 \pm 0.009$ & $0.802 \pm 0.077$ & $12.3 \pm 1.18$ & $-22.184 \pm 0.745$ & $41.3 \pm 0.328$ & $-5.393 \pm 0.864$ & $0.869 \pm 0.151$ \\
\hline & & \multirow{2}{*}{ Sterna vittata } & & Ramalina terebrata & 3 & \pm 0.018 & $1 \pm 0.037$ & 0.01 & $9.93 \pm$ & 0. & 2.2 & $10.6 \pm$ & $-24.832 \pm 0.335$ & $34.1 \pm 2.38$ & $-2.575 \pm 0.336$ & $0.923 \pm 0 . c$ \\
\hline & & & & Usnea aurantiaco-ater & 3 & $0.405 \pm 0.039$ & $0.220 \pm 0.015$ & $0.019 \pm 0.001$ & $5.12 \pm 0.325$ & $0.460 \pm 0.034$ & $1.77 \pm 0.098$ & $9.25 \pm 0.450$ & $-23.389 \pm 0.332$ & $39.2 \pm 0.299$ & $-7.417 \pm 0.159$ & $0.724 \pm 0.05$ \\
\hline
\end{tabular}




\begin{tabular}{|c|c|c|c|c|c|c|c|c|c|c|c|c|c|c|c|}
\hline Main Location & Specific Location & Colony species & Matrix Species & $n$ & $\mathrm{Hg}$ & As & $\mathrm{Cd}$ & $\mathrm{Cu}$ & $\mathrm{Pb}$ & $\mathrm{Se}$ & $\mathrm{Zn}$ & $\delta^{13 \mathrm{C}}$ & $\% c$ & $8^{15} \mathrm{~N}$ & $\% \mathrm{~N}$ \\
\hline Deception Island & | Deception Island | & Control & Bryum pseudotrichetrum & 4 & $0.077 \pm 0.092$ & $0.737 \pm 0.534$ & $0.045 \pm 0.012$ & $11.3 \pm 5.41$ & $0.172 \pm 0.100$ & $1.16 \pm 0.692$ & $29.2 \pm 12.9$ & $-25.235 \pm 1.34$ & $34.2 \pm 12.6$ & $1.60 \pm 6.59$ & $1.80 \pm 0.777$ \\
\hline \multirow{2}{*}{ Half Moon } & & Control & Sanionia uncinata & 3 & $0.039 \pm 0.002$ & $0.146 \pm 0.033$ & $0.331 \pm 0.029$ & $14.4 \pm 1.54$ & $0.127 \pm 0.035$ & $1.62 \pm 0.218$ & $20.9 \pm 1.97$ & $-24.298 \pm 0.213$ & $43.6 \pm 0.392$ & $13.1 \pm 0.735$ & $2.27 \pm 0.315$ \\
\hline & & Pygoscelis antarcticus & Prasiola crispa & 3 & $0.084 \pm 0.007$ & $1.25 \pm 0.331$ & $0.459 \pm 0.078$ & $23.6 \pm 10.1$ & $0.215 \pm 0.074$ & $4.41 \pm 0.998$ & $38.9 \pm 8.65$ & $-21.493 \pm 1.08$ & $42.2 \pm 1.57$ & $0.426 \pm 0.988$ & $6.53 \pm 0.130$ \\
\hline \multirow{10}{*}{ KGI } & Cape Vauréal & Macronectes giganteus & Colobanthus & 3 & $0.021 \pm 0.004$ & $1.26 \pm 0.359$ & $0.568 \pm 0.381$ & $32.7 \pm 8.82$ & $0.767 \pm 0.247$ & $1.50 \pm 0.388$ & $45.6 \pm 6.63$ & $-26.233 \pm 0.172$ & $28.0 \pm 6.61$ & $8.79 \pm 1.18$ & $1.28 \pm 0.235$ \\
\hline & Cape vaureal & & Polytrichastrum alpinum & 3 & $0.075 \pm 0.006$ & $1.37 \pm 0.431$ & $0.072 \pm 0.006$ & $65.8 \pm 18.4$ & $0.436 \pm 0.144$ & $1.93 \pm 0.310$ & $26.4 \pm 5.51$ & $-26.085 \pm 0.395$ & $37.9 \pm 3.96$ & $12.2 \pm 0.593$ & $1.06 \pm 0.071$ \\
\hline & Chabrier Rock & Pygoscelis antarcticus & Prasiola crispa & 3 & $0.066 \pm 0.004$ & $3.19 \pm 0.251$ & $0.206 \pm 0.023$ & $44.4 \pm 3.00$ & $0.142 \pm 0.023$ & $6.40 \pm 0.606$ & $56.7 \pm 1.93$ & $-20.553 \pm 0.187$ & $35.9 \pm 2.59$ & $12.8 \pm 0.793$ & $5.61 \pm 0.360$ \\
\hline & Ferraz & Control & Sanionia uncinata & 3 & $0.336 \pm 0.060$ & $0.793 \pm 0.310$ & $0.132 \pm 0.081$ & $10.9 \pm 3.05$ & $0.921 \pm 0.447$ & $1.33 \pm 0.380$ & $23.1 \pm 5.69$ & $-27.509 \pm 0.401$ & $41.6 \pm 1.53$ & $6.27 \pm 0.901$ & $1.11 \pm 0.276$ \\
\hline & Punta Hennequin | & Catharacta $s p^{*}$ & Sanionia uncinata & 3 & $0.081 \pm 0.001$ & $0.559 \pm 0.114$ & $0.192 \pm 0.069$ & $4.56 \pm 0.237$ & $0.192 \pm 0.116$ & $0.904 \pm 0.241$ & $21.6 \pm 0.945$ & $-25.882 \pm 0.473$ & $43.7 \pm 0.924$ & $9.51 \pm 0.406$ & $2.04 \pm 0.094$ \\
\hline & Punta Ullmann & Larus dominicanus* & Sanionia uncinata & 3 & $0.107 \pm 0.016$ & $1.80 \pm 0.134$ & $0.091 \pm 0.007$ & $26.5 \pm 3.03$ & $0.883 \pm 0.124$ & $1.71 \pm 0.223$ & $29.5 \pm 2.99$ & $-25.439 \pm 0.424$ & $35.4 \pm 1.27$ & $2.93 \pm 0.742$ & $1.65 \pm 0.168$ \\
\hline & Stenhouse & Larus dominicanus* & Sanionia uncinata & 3 & $0.078 \pm 0.015$ & $3.60 \pm 1.01$ & $0.790 \pm 0.397$ & $55.6 \pm 8.61$ & $2.27 \pm 0.745$ & $2.72 \pm 0.313$ & $35.6 \pm 8.30$ & $-25.374 \pm 0.599$ & $31.4 \pm 6.35$ & $2.33 \pm 0.241$ & $1.52 \pm 0.410$ \\
\hline & & Control & Sanionia uncinata & 3 & $0.123 \pm 0.006$ & $1.56 \pm 0.101$ & $0.215 \pm 0.010$ & $16.0 \pm 5.94$ & $0.447 \pm 0.047$ & $3.19 \pm 0.213$ & $27.1 \pm 11.3$ & $-25.629 \pm 0.172$ & $33.0 \pm 1.05$ & $11.9 \pm 0.113$ & $2.62 \pm 0.034$ \\
\hline & & Pygoscelis adeliae & Sanionia uncinata & 3 & $0.046 \pm 0.002$ & $0.544 \pm 0.047$ & $0.180 \pm 0.007$ & $15.9 \pm 1.45$ & $0.170 \pm 0.024$ & $1.28 \pm 0.122$ & $37.1 \pm 1.87$ & $-26.593 \pm 0.342$ & $39.5 \pm 0.939$ & $11.5 \pm 0.140$ & $1.86 \pm 0.062$ \\
\hline & Yellow Point & Control & Syntrichia sp & 1 & 0.069 & 7.09 & 0.176 & 49.5 & 3.47 & 2.29 & 28.2 & -25.562 & 31.9 & 7.08 & 1.17 \\
\hline \multirow{4}{*}{ Livingston } & \multirow{4}{*}{ Hannah Point } & Macronectes giganteus & Prasiola crispa & 3 & $0.059 \pm 0.007$ & $3.02 \pm 0.436$ & $0.537 \pm 0.036$ & $14.8 \pm 0.943$ & $0.525 \pm 0.204$ & $3.43 \pm 0.378$ & $33.9 \pm 4.19$ & $-28.007 \pm 0.166$ & $35.4 \pm 2.28$ & $12.7 \pm 0.832$ & $3.85 \pm 0.256$ \\
\hline & & Phalacrocorax atriceps & Prasiola crispa & 3 & $0.177 \pm 0.019$ & $3.47 \pm 0.869$ & $1.46 \pm 0.548$ & $59.3 \pm 50.4$ & $0.356 \pm 0.023$ & $5.13 \pm 1.43$ & $209 \pm 39.6$ & $-21.806 \pm 0.267$ & $20.2 \pm 4.53$ & $21.0 \pm 2.81$ & $3.53 \pm 0.621$ \\
\hline & & Pygoscelis antarcticus & Prasiola crispa & 2 & $0.077 \pm 0.001$ & $3.93 \pm 0.265$ & $1.37 \pm 0.193$ & $53.6 \pm 16.8$ & $0.629 \pm 0.201$ & $9.44 \pm 1.16$ & $88.9 \pm 22.5$ & $-24.147 \pm 0.114$ & $25.6 \pm 3.45$ & $16.5 \pm 0.727$ & $3.85 \pm 0.461$ \\
\hline & & Pygoscelis papua & Prasiola crispa & 3 & $0.030 \pm 0.006$ & $3.80 \pm 0.459$ & $0.157 \pm 0.024$ & $17.3 \pm 2.97$ & $0.649 \pm 0.063$ & $3.03 \pm 0.177$ & $32.1 \pm 5.02$ & $-20.161 \pm 0.400$ & $26.6 \pm 3.32$ & $15.1 \pm 0.352$ & $4.06 \pm 0.588$ \\
\hline Nelson Island & Nelson Island | & Daption capense $* *$ & Sanionia uncinata & 3 & $0.167 \pm 0.013$ & $1.28 \pm 0.172$ & $0.263 \pm 0.031$ & $15.3 \pm 0.712$ & $0.198 \pm 0.034$ & $1.78 \pm 0.102$ & $19.8 \pm 1.58$ & $-25.513 \pm 0.282$ & $43.0 \pm 0.890$ & $19.5 \pm 0.581$ & $3.01 \pm 0.219$ \\
\hline \multirow{2}{*}{ Penguin Island } & \multirow{2}{*}{ Penguin Island } & Control & Polytrichastrum alpinum & 3 & $0.037 \pm 0.003$ & 0.221 & $0.134 \pm 0.017$ & $14.1 \pm 7.11$ & $0.146 \pm 0.099$ & 0.481 & $19.7 \pm 1.94$ & $-27.178 \pm 0.117$ & $40.0 \pm 6.86$ & $5.43 \pm 0.205$ & $1.12 \pm 0.255$ \\
\hline & & Pygoscelis antarcticus & Prasiola crispa & 3 & $0.086 \pm 0.013$ & $3.09 \pm 0.575$ & $0.987 \pm 0.488$ & $73.6 \pm 18.9$ & $0.186 \pm 0.022$ & $10.1 \pm 4.29$ & $138 \pm 49.6$ & $-21.733 \pm 0.448$ & $37.6 \pm 1.85$ & $5.80 \pm 1.08$ & $6.83 \pm 0.404$ \\
\hline
\end{tabular}




\begin{tabular}{|c|c|c|c|c|c|c|c|c|c|c|c|c|c|c|}
\hline Main Location & Specific Location & Colony species & $n$ & $\mathrm{Hg}$ & As & $\mathrm{Cd}$ & $\mathrm{Cu}$ & $\mathrm{Pb}$ & $\mathrm{Se}$ & $\mathrm{Zn}$ & $\delta^{13} \mathrm{C}$ & $\% \mathrm{C}$ & $8^{15} \mathrm{~N}$ & $\% \mathrm{~N}$ \\
\hline Deception Island & Deception Island | & Control & 3 & $0.006 \pm 0.000$ & $0.711 \pm 0.086$ & & $7.66 \pm 0.715$ & $0.268 \pm 0.020$ & $0.693 \pm 0.073$ & $16.2 \pm 0.875$ & $-25.752 \pm 0.234$ & $0.095 \pm 0.046$ & $29.6 \pm 3.12$ & $0.053 \pm 0.008$ \\
\hline Half Moon & Half Moon | & Pygoscelis antarcticus & 3 & $0.247 \pm 0.044$ & $6.37 \pm 1.22$ & $4.92 \pm 0.586$ & $419 \pm 39.4$ & $0.249 \pm 0.093$ & $30.9 \pm 1.53$ & $388 \pm 60.3$ & $-28.470 \pm 0.529$ & $17.2 \pm 2.12$ & $20.1 \pm 0.942$ & $4.42 \pm 0.262$ \\
\hline \multirow{6}{*}{ KGI } & Chabrier Rock | & Pygoscelis antarcticus & 3 & $0.192 \pm 0.020$ & $8.09 \pm 1.29$ & $2.93 \pm 1.26$ & $316 \pm 115$ & $0.055 \pm 0.003$ & $27.4 \pm 8.62$ & $260 \pm 84.6$ & $-28.079 \pm 0.924$ & $21.6 \pm 1.98$ & $13.5 \pm 5.19$ & $9.58 \pm 4.48$ \\
\hline & Shag Island | & Phalacrocorax atriceps & 3 & $0.194 \pm 0.012$ & $3.89 \pm 0.236$ & $1.46 \pm 0.043$ & $59.5 \pm 4.35$ & $0.115 \pm 0.018$ & $6.43 \pm 0.705$ & $255 \pm 1.09$ & $-24.745 \pm 0.409$ & $9.87 \pm 1.40$ & $30.9 \pm 0.802$ & $2.76 \pm 0.408$ \\
\hline & & Control & 3 & $0.013 \pm 0.004$ & $1.53 \pm 0.134$ & & $22.0 \pm 1.83$ & $0.519 \pm 0.089$ & $1.03 \pm 0.141$ & $39.5 \pm 2.73$ & $-23.414 \pm 0.294$ & $0.540 \pm 0.335$ & $13.0 \pm 7.42$ & $0.156 \pm 0.073$ \\
\hline & Turret Point & Phalacrocorax atriceps & 3 & $0.197 \pm 0.025$ & $6.08 \pm 1.33$ & $2.34 \pm 0.246$ & $50.1 \pm 4.13$ & $0.190 \pm 0.045$ & $9.14 \pm 1.10$ & $467 \pm 11.9$ & $-24.508 \pm 0.401$ & $8.66 \pm 1.11$ & $30.7 \pm 0.718$ & $2.52 \pm 0.359$ \\
\hline & & Pygoscelis adeliae & 3 & $0.091 \pm 0.006$ & $4.23 \pm 0.224$ & $2.60 \pm 0.375$ & $264 \pm 28.3$ & $0.507 \pm 0.041$ & $22.7 \pm 3.52$ & $385 \pm 42.8$ & $-26.813 \pm 0.267$ & $9.65 \pm 2.24$ & $16.8 \pm 0.746$ & $2.03 \pm 0.458$ \\
\hline & Yellow Point | & Control & 1 & 0.009 & 19.3 & 0.328 & 80.6 & 4.45 & 3.69 & 81.7 & -22.081 & 0.814 & 9.12 & 0.097 \\
\hline \multirow{3}{*}{ Livingston } & \multirow{3}{*}{ Hannah Point } & Phalacrocorax atriceps & 3 & $0.168 \pm 0.002$ & $4.32 \pm 0.693$ & $1.42 \pm 0.401$ & $30.9 \pm 6.01$ & $0.208 \pm 0.109$ & $4.92 \pm 0.300$ & $262 \pm 50.7$ & $-24.423 \pm 0.330$ & $7.54 \pm 1.42$ & $25.7 \pm 2.06$ & $1.94 \pm 0.626$ \\
\hline & & Pygoscelis antarcticus & 3 & $0.133 \pm 0.025$ & $5.05 \pm 0.158$ & $1.60 \pm 0.204$ & $157 \pm 14.9$ & $0.843 \pm 0.053$ & $14.1 \pm 1.63$ & $177 \pm 15.1$ & $-28.139 \pm 0.317$ & $8.84 \pm 0.938$ & $18.8 \pm 0.137$ & $1.95 \pm 0.186$ \\
\hline & & Pygoscelis papua & 3 & $0.028 \pm 0.006$ & $4.36 \pm 0.198$ & $0.132 \pm 0.003$ & $49.1 \pm 1.71$ & $1.45 \pm 0.038$ & $4.54 \pm 0.047$ & $64.0 \pm 1.41$ & $-27.402 \pm 0.560$ & $1.55 \pm 0.127$ & $22.4 \pm 1.78$ & $0.523 \pm 0.051$ \\
\hline \multirow{2}{*}{ Penguin Island } & \multirow{2}{*}{ Penguin Island } & Control & 3 & $0.007 \pm 0.001$ & $0.470 \pm 0.019$ & & $47.8 \pm 3.54$ & $0.460 \pm 0.043$ & $0.549 \pm 0.026$ & $29.9 \pm 1.73$ & $-22.317 \pm 0.232$ & $1.23 \pm 0.392$ & $18.8 \pm 0.441$ & $0.228 \pm 0.076$ \\
\hline & & Pygoscelis adeliae & 3 & $0.290 \pm 0.014$ & $8.39 \pm 0.878$ & $4.94 \pm 0.636$ & $416 \pm 80.6$ & $0.088 \pm 0.034$ & $34.8 \pm 5.55$ & $444 \pm 13.2$ & $-28.461 \pm 0.462$ & $24.6 \pm 2.22$ & $17.4 \pm 1.53$ & $5.72 \pm 0.637$ \\
\hline
\end{tabular}




\begin{tabular}{|c|c|c|c|}
\hline & & Control sites & Colony sites \\
\hline \multirow{17}{*}{$\begin{array}{l}\text { Liche } \\
\text { n }\end{array}$} & $\mathrm{Hg}$ & & $+P b,+S e,-Z n,-\delta^{15} N,-\% N$ \\
\hline & As & $+\mathrm{Cd},+\mathrm{Co},+\mathrm{Cr},+\mathrm{Cu},+\mathrm{Fe},+\mathrm{Mn},-\mathrm{V},+\mathrm{Zn},-\% \mathrm{C},+\% \mathrm{~N}$ & $-\mathrm{Co},-\mathrm{Ni},+\mathrm{Zn},+\% \mathrm{C},+\delta^{15} \mathrm{~N},+\% \mathrm{~N}$ \\
\hline & $\mathrm{Cd}$ & + As, $+C \mathrm{Cu},+\mathrm{Zn},+\% \mathrm{~N}$ & $+\mathrm{Cu},+\delta^{15} \mathrm{~N},+\% \mathrm{~N}$ \\
\hline & Co & $+\mathrm{As},+\mathrm{Cr},+\mathrm{Cu},+\mathrm{Fe},+\mathrm{Mn},+\mathrm{Ni},-\mathrm{Se},-\mathrm{V},+\delta^{15} \mathrm{~N},+\% \mathrm{~N}$ & $-\mathrm{As},+\mathrm{Cr},+\mathrm{Cu},+\mathrm{Fe},+\mathrm{Mn},+\mathrm{Ni},+\mathrm{Pb},+\mathrm{Se},-\mathrm{V},-\% \mathrm{C},-\delta^{15} \mathrm{~N}$ \\
\hline & $\mathrm{Cr}$ & $+\mathrm{As},+\mathrm{Co},+\mathrm{Cu},+\mathrm{Fe},+\mathrm{Mn},+\mathrm{Ni},-\mathrm{V},+\% \mathrm{~N}$ & $+\mathrm{Co},+\mathrm{Cu},+\mathrm{Fe},+\mathrm{Mn},+\mathrm{Ni},+\mathrm{Pb},+\mathrm{Se},-\% \mathrm{C},-\delta^{15} \mathrm{~N}$ \\
\hline & $\mathrm{Cu}$ & $\begin{array}{c}+\mathrm{As},+\mathrm{Cd},+\mathrm{Co},+\mathrm{Cr},+\mathrm{Fe},+\mathrm{Mn},+\mathrm{Ni},-\mathrm{V},+\mathrm{Zn},+\delta^{15} \mathrm{~N} \\
+\% \mathrm{~N}\end{array}$ & $+\mathrm{Cd},+\mathrm{Co},+\mathrm{Cr},+\mathrm{Fe},+\mathrm{Mn},+\mathrm{Ni},+\mathrm{Zn},-\delta^{13} \mathrm{C},-\% \mathrm{C},+\% \mathrm{~N}$ \\
\hline & $\mathrm{Fe}$ & $+\mathrm{As},+\mathrm{Co},+\mathrm{Cr},+\mathrm{Cu},+\mathrm{Mn},+\mathrm{Ni},-\mathrm{V},+\% \mathrm{~N}$ & $+\mathrm{Co},+\mathrm{Cr},+\mathrm{Cu},+\mathrm{Mn},+\mathrm{Ni},+\mathrm{Pb},+\mathrm{Se},-\mathrm{V},-\% \mathrm{C},-\delta^{15} \mathrm{~N}$ \\
\hline & $\mathrm{Mn}$ & $+\mathrm{As},+\mathrm{Co},+\mathrm{Cr},+\mathrm{Cu},+\mathrm{Fe},+\mathrm{Ni},-\mathrm{V},+\% \mathrm{~N}$ & $+\mathrm{Co},+\mathrm{Cr},+\mathrm{Cu},+\mathrm{Fe},+\mathrm{Ni},+\mathrm{Pb},-\mathrm{V},+\mathrm{Zn},-\delta^{13} \mathrm{C},-\% \mathrm{C}$ \\
\hline & $\mathrm{Ni}$ & $+\mathrm{Co},+\mathrm{Cr},+\mathrm{Cu},+\mathrm{Fe},+\mathrm{Mn},-\mathrm{Pb},-\mathrm{Se},-\mathrm{V},-\delta^{13} \mathrm{C},+\% \mathrm{~N}$ & $-\mathrm{As},+\mathrm{Co},+\mathrm{Cr},+\mathrm{Cu},+\mathrm{Fe},+\mathrm{Mn},+\mathrm{Pb},+\mathrm{Se},-\mathrm{V},-\frac{}{\mathrm{C}}$ \\
\hline & $\mathrm{Pb}$ & $-\mathrm{Ni},+\mathrm{Se},+\delta^{13} \mathrm{C}$ & $+\mathrm{Hg},+\mathrm{Co},+\mathrm{Cr},+\mathrm{Fe},+\mathrm{Mn},+\mathrm{Ni},+\mathrm{Se},-\delta^{15} \mathrm{~N},-\% \mathrm{~N}$ \\
\hline & Se & $-\mathrm{Co},-\mathrm{Ni},+\mathrm{Pb}$ & $+\mathrm{Hg},+\mathrm{Co},+\mathrm{Cr},+\mathrm{Fe},+\mathrm{Ni},+\mathrm{Pb},-\% \mathrm{C},-\delta^{15} \mathrm{~N},-\% \mathrm{~N}$ \\
\hline & $\mathrm{V}$ & $-A s,-C o,-C r,-C u,-F e,-M n,-N i,-\delta^{15} N,-\% N$ & $-\mathrm{Co},-\mathrm{Fe},-\mathrm{Mn},-\mathrm{Ni},+\% \mathrm{C},+\delta^{15} \mathrm{~N}$ \\
\hline & $\mathrm{Zn}$ & $+\mathrm{As},+\mathrm{Cd},+\mathrm{Cu},+\% \mathrm{~N}$ & $-\mathrm{Hg},+\mathrm{As},+\mathrm{Cu},+\mathrm{Mn},+\delta^{15} \mathrm{~N},+\% \mathrm{~N}$ \\
\hline & $\delta^{13} \mathrm{C}$ & $-\mathrm{Ni},+\mathrm{Pb}$ & $-\mathrm{Cu},-\mathrm{Mn}$ \\
\hline & $\% \mathrm{C}$ & -As & $+\mathrm{As},-\mathrm{Co},-\mathrm{Cr},-\mathrm{Cu},-\mathrm{Fe},-\mathrm{Mn},-\mathrm{Ni},-\mathrm{Se},+\mathrm{V}$ \\
\hline & $\begin{array}{c}\delta^{15} \\
\mathrm{~N}\end{array}$ & $+\mathrm{Co},+\mathrm{Cu},-\mathrm{V},+\% \mathrm{~N}$ & $-\mathrm{Hg},+\mathrm{As},+\mathrm{Cd},-\mathrm{Co},-\mathrm{Cr},-\mathrm{Fe},-\mathrm{Pb},-\mathrm{Se},+\mathrm{V},+\mathrm{Zn},+\% \mathrm{~N}$ \\
\hline & $\% \mathrm{~N}$ & $\begin{aligned}+\mathrm{As},+\mathrm{Cd},+\mathrm{Co},+\mathrm{Cr},+\mathrm{Cu},+\mathrm{Fe},+\mathrm{Mn},+\mathrm{Ni},-\mathrm{V},+\mathrm{Zn} \\
+\delta^{15} \mathrm{~N}\end{aligned}$ & $-\mathrm{Hg},+\mathrm{As},+\mathrm{Cd},+\mathrm{Cu},-\mathrm{Pb},-\mathrm{Se},+\mathrm{Zn},+\delta^{15} \mathrm{~N}$ \\
\hline \multirow{17}{*}{ Moss } & $\mathrm{Hg}$ & $+\mathrm{Pb}$ & $-\mathrm{Co},-\mathrm{Cr},-\mathrm{Ni}$ \\
\hline & As & $+\mathrm{Co},+\mathrm{Cr},+\mathrm{Fe},+\mathrm{Ni},+\mathrm{Se}$ & $+\mathrm{Cd},+\mathrm{Cu},+\mathrm{Fe},+\mathrm{Mn},+\mathrm{Pb},+\mathrm{Se},+\mathrm{Zn},+\delta^{13} \mathrm{C},-\% \mathrm{C},+\% \mathrm{~N}$ \\
\hline & $\mathrm{Cd}$ & $+\mathrm{V},+\delta^{15} \mathrm{~N},+\% \mathrm{~N}$ & $+\mathrm{As},+\mathrm{Se},+\mathrm{Zn},-\% \mathrm{C},+\% \mathrm{~N}$ \\
\hline & Co & $+\mathrm{As},+\mathrm{Cr},+\mathrm{Cu},+\mathrm{Fe},+\mathrm{Mn},+\mathrm{Ni},+\mathrm{Zn},-\frac{}{\mathrm{C}} \mathrm{C}$ & $-\mathrm{Hg},+\mathrm{Cr},+\mathrm{Fe},+\mathrm{Mn},+\mathrm{Ni},+\mathrm{Pb},+\mathrm{V},-\delta^{13} \mathrm{C},-\% \mathrm{C},-\% \mathrm{~N}$ \\
\hline & $\mathrm{Cr}$ & $+\mathrm{As},+\mathrm{Co},+\mathrm{Fe},+\mathrm{Mn},+\mathrm{Ni},-\% \mathrm{C}$ & $-\mathrm{Hg},+\mathrm{Co},+\mathrm{Cu},+\mathrm{Fe},+\mathrm{Mn},+\mathrm{Ni},+\mathrm{Zn},-\% \mathrm{C}$ \\
\hline & $\mathrm{Cu}$ & $+\mathrm{Co},+\mathrm{Fe},+\mathrm{Mn},+\mathrm{V},+\mathrm{Zn},-\frac{\mathrm{C},}{,}+\delta^{15} \mathrm{~N}$ & $+\mathrm{As},+\mathrm{Cr},+\mathrm{Fe},+\mathrm{Mn},+\mathrm{Ni},+\mathrm{Se},+\mathrm{Zn},-\% \mathrm{C}$ \\
\hline & $\mathrm{Fe}$ & $+\mathrm{As},+\mathrm{Co},+\mathrm{Cr},+\mathrm{Cu},+\mathrm{Mn},+\mathrm{Ni},+\mathrm{Pb},-\% \mathrm{C}$ & $+\mathrm{As},+\mathrm{Co},+\mathrm{Cr},+\mathrm{Cu},+\mathrm{Mn},+\mathrm{Ni},+\mathrm{Pb},+\mathrm{V},+\mathrm{Zn},-\% \mathrm{C},-\% \mathrm{~N}$ \\
\hline & $\mathrm{Mn}$ & $+\mathrm{Co},+\mathrm{Cr},+\mathrm{Cu},+\mathrm{Fe},+\mathrm{Ni},+\mathrm{Zn},-\% \mathrm{C}$ & $+\mathrm{As},+\mathrm{Co},+\mathrm{Cr},+\mathrm{Cu},+\mathrm{Fe},+\mathrm{Ni},+\mathrm{Pb},+\mathrm{V},+\mathrm{Zn},-\% \mathrm{C},-\frac{}{\mathrm{N}}$ \\
\hline & $\mathrm{Ni}$ & $+\mathrm{As},+\mathrm{Co},+\mathrm{Cr},+\mathrm{Fe},+\mathrm{Mn},-\% \mathrm{C}$ & $-\mathrm{Hg},+\mathrm{Co},+\mathrm{Cr},+\mathrm{Cu},+\mathrm{Fe},+\mathrm{Mn},+\mathrm{Zn},-\delta^{13} \mathrm{C},-\frac{}{2} \mathrm{C},-\% \mathrm{~N}$ \\
\hline & $\mathrm{Pb}$ & $+\mathrm{Hg},+\mathrm{Fe}$ & $+\mathrm{As},+\mathrm{Co},+\mathrm{Fe},+\mathrm{Mn},+\mathrm{V},-\% \mathrm{C},-\% \mathrm{~N}$ \\
\hline & $\mathrm{Se}$ & + As & + As, $+C d,+C u,+Z n,+\delta^{13} C,-\% C,+\% N$ \\
\hline & $\mathrm{V}$ & $+\mathrm{Cd},+\mathrm{Cu},+\delta^{15} \mathrm{~N}$ & $+\mathrm{Co},+\mathrm{Fe},+\mathrm{Mn},+\mathrm{Pb},-\% \mathrm{C},-\% \mathrm{~N}$ \\
\hline & $\mathrm{Zn}$ & $+\mathrm{Co},+\mathrm{Cu},+\mathrm{Mn}$ & $+\mathrm{As},+\mathrm{Cd},+\mathrm{Cr},+\mathrm{Cu},+\mathrm{Fe},+\mathrm{Mn},+\mathrm{Ni},+\mathrm{Se},+\delta^{13} \mathrm{C},-\% \mathrm{C},+\% \mathrm{~N}$ \\
\hline & $\delta^{13} \mathrm{C}$ & $+\% \mathrm{~N}$ & + As, $-\mathrm{Co},-\mathrm{Ni},+\mathrm{Se},+\mathrm{Zn},+\% \mathrm{~N}$ \\
\hline & $\% \mathrm{C}$ & $-\mathrm{Co},-\mathrm{Cr},-\mathrm{Cu},-\mathrm{Fe},-\mathrm{Mn},-\mathrm{Ni}$ & $-A s,-C d,-C o,-C r,-C u,-F e,-M n,-N i,-P b,-S e,-V,-Z n$ \\
\hline & $\delta^{15}$ & $+\mathrm{Cd},+\mathrm{Cu},+\mathrm{V}$ & \\
\hline & $\% \mathrm{~N}$ & $+\mathrm{Cd},+\delta^{13} \mathrm{C}$ & $+\mathrm{As},+\mathrm{Cd},-\mathrm{Co},-\mathrm{Fe},-\mathrm{Mn},-\mathrm{Ni},-\mathrm{Pb},+\mathrm{Se},-\mathrm{V},+\mathrm{Zn},+\delta^{13} \mathrm{C}$ \\
\hline \multirow{17}{*}{ Soil } & $\mathrm{Hg}$ & $+\mathrm{Co},+\mathrm{Fe},+\mathrm{Mn},+\mathrm{Pb},+\mathrm{Se},+\mathrm{Zn},-\delta^{15} \mathrm{~N}$ & $+\mathrm{As},+\mathrm{Cd},-\mathrm{Co},+\mathrm{Cu},-\mathrm{Fe},-\mathrm{Mn},-\mathrm{Pb},+\mathrm{Se},-\mathrm{V},+\mathrm{Zn},+\% \mathrm{C},+\% \mathrm{~N}$ \\
\hline & As & $+\mathrm{Se}$ & $+\mathrm{Hg},+\mathrm{Cd},-\mathrm{Co},+\mathrm{Cu},-\mathrm{Mn},-\mathrm{Pb},+\mathrm{Se},-\mathrm{V},-\delta^{13} \mathrm{C},+\% \mathrm{C},-\delta^{15} \mathrm{~N},+\% \mathrm{~N}$ \\
\hline & $\mathrm{Cd}$ & & $+\mathrm{Hg},+\mathrm{As},-\mathrm{Co},+\mathrm{Cu},-\mathrm{Mn},-\mathrm{Pb},+\mathrm{Se},-\mathrm{V},+\mathrm{Zn},-\delta^{13} \mathrm{C},+\% \mathrm{C},-\delta^{15} \mathrm{~N},+\% \mathrm{~N}$ \\
\hline & Co & $+\mathrm{Hg},+\mathrm{Cr},+\mathrm{Fe},+\mathrm{Mn},+\mathrm{Ni},+\mathrm{Zn},+\% \mathrm{~N}$ & $-\mathrm{Hg},-\mathrm{As},-\mathrm{Cd},+\mathrm{Cr},-\mathrm{Cu},+\mathrm{Fe},+\mathrm{Mn},+\mathrm{Pb},-\mathrm{Se},+\mathrm{V},-\% \mathrm{C},-\% \mathrm{~N}$ \\
\hline & $\mathrm{Cr}$ & $+\mathrm{Co},+\mathrm{Ni},+\% \mathrm{~N}$ & $+\mathrm{Co},+\mathrm{Fe},+\mathrm{Ni},+\mathrm{Pb},+\mathrm{V},+\mathrm{Zn}$ \\
\hline & $\mathrm{Cu}$ & $+\mathrm{Pb},+\mathrm{V},+\delta^{13} \mathrm{C},+\% \mathrm{C},-\delta^{15} \mathrm{~N}$ & $+\mathrm{Hg},+\mathrm{As},+\mathrm{Cd},-\mathrm{Co},-\mathrm{Mn},+\mathrm{Se},+\mathrm{Zn},-\delta^{13} \mathrm{C},+\% \mathrm{C},-\delta^{15} \mathrm{~N},+\% \mathrm{~N}$ \\
\hline & $\mathrm{Fe}$ & $+\mathrm{Hg},+\mathrm{Co},+\mathrm{Mn},+\mathrm{Pb},+\mathrm{Zn},-\delta^{15} \mathrm{~N}$ & $-\mathrm{Hg},+\mathrm{Co},+\mathrm{Cr},+\mathrm{Mn},+\mathrm{Pb},+\mathrm{V},-\% \mathrm{C},-\% \mathrm{~N}$ \\
\hline & $\mathrm{Mn}$ & $+\mathrm{Hg},+\mathrm{Co},+\mathrm{Fe},+\mathrm{Pb},+\mathrm{Zn},+\delta^{13} \mathrm{C},-\delta^{15} \mathrm{~N}$ & $-\mathrm{Hg},-\mathrm{As},-\mathrm{Cd},+\mathrm{Co},-\mathrm{Cu},+\mathrm{Fe},+\mathrm{Pb},-\mathrm{Se},+\mathrm{V},-\mathrm{Zn},-\% \mathrm{C},-\% \mathrm{~N}$ \\
\hline & $\mathrm{Ni}$ & $+\mathrm{Co},+\mathrm{Cr},+\% \mathrm{~N}$ & $+\mathrm{Cr},+\mathrm{Zn},+\delta^{13} \mathrm{C}$ \\
\hline & $\mathrm{Pb}$ & $+\mathrm{Hg},+\mathrm{Cu},+\mathrm{Fe},+\mathrm{Mn},+\mathrm{V},+\mathrm{Zn},-\delta^{15} \mathrm{~N}$ & $-\mathrm{Hg},-\mathrm{As},-\mathrm{Cd},+\mathrm{Co},+\mathrm{Cr},+\mathrm{Fe},+\mathrm{Mn},-\mathrm{Se},+\mathrm{V},-\% \mathrm{C},-\% \mathrm{~N}$ \\
\hline & $\mathrm{Se}$ & $+\mathrm{Hg},+\mathrm{As}$ & $+\mathrm{Hg},+\mathrm{As},+\mathrm{Cd},-\mathrm{Co},+\mathrm{Cu},-\mathrm{Mn},-\mathrm{Pb},-\mathrm{V},+\mathrm{Zn},-\delta^{13} \mathrm{C},+\% \mathrm{C},-\delta^{15} \mathrm{~N},+\% \mathrm{~N}$ \\
\hline & V & $+\mathrm{Cu},+\mathrm{Pb},+\delta^{13} \mathrm{C},+\% \mathrm{C},-\delta^{15} \mathrm{~N}$ & $-\mathrm{Hg},-\mathrm{As},-\mathrm{Cd},+\mathrm{Co},+\mathrm{Cr},+\mathrm{Fe},+\mathrm{Mn},+\mathrm{Pb},-\mathrm{Se},-\mathrm{Zn},-\% \mathrm{C},-\% \mathrm{~N}$ \\
\hline & $\mathrm{Zn}$ & $+\mathrm{Hg},+\mathrm{Co},+\mathrm{Fe},+\mathrm{Mn},+\mathrm{Pb},-\delta^{15} \mathrm{~N}$ & $+\mathrm{Hg},+\mathrm{Cd},+\mathrm{Cr},+\mathrm{Cu},-\mathrm{Mn},+\mathrm{Ni},+\mathrm{Se},-\mathrm{V},+\% \mathrm{C},+\% \mathrm{~N}$ \\
\hline & $\delta^{13} \mathrm{C}$ & $+\mathrm{Cu},+\mathrm{Mn},+\mathrm{V},+\% \mathrm{C},-\delta^{15} \mathrm{~N},+\% \mathrm{~N}$ & $-\mathrm{As},-\mathrm{Cd},-\mathrm{Cu},+\mathrm{Ni},-\mathrm{Se},-\% \mathrm{C},+\delta^{15} \mathrm{~N}$ \\
\hline & $\% \mathrm{C}$ & $+\mathrm{Cu},+\mathrm{V},+\delta^{13} \mathrm{C},-\delta^{15} \mathrm{~N},+\% \mathrm{~N}$ & $\begin{array}{c}+\mathrm{Hg},+\mathrm{As},+\mathrm{Cd},-\mathrm{Co},+\mathrm{Cu},-\mathrm{Fe},-\mathrm{Mn},-\mathrm{Pb},+\mathrm{Se},-\mathrm{V},+\mathrm{Zn},-\delta^{13} \mathrm{C},-\delta^{15} \mathrm{~N}, \\
+\% \mathrm{~N}\end{array}$ \\
\hline & $\begin{array}{c}\delta^{15} \\
\mathrm{~N}\end{array}$ & $-H g,-C u,-F e,-M n,-P b,-V,-Z n,-\delta^{13} C,-\% C$ & $-A s,-C d,-C u,-S e,+\delta^{13} C,-\% C$ \\
\hline & $\% \mathrm{~N}$ & $+\mathrm{Co},+\mathrm{Cr},+\mathrm{Ni},+\delta^{13} \mathrm{C},+\% \mathrm{C}$ & $+\mathrm{Hg},+\mathrm{As},+\mathrm{Cd},-\mathrm{Co},+\mathrm{Cu},-\mathrm{Fe},-\mathrm{Mn},-\mathrm{Pb},+\mathrm{Se},-\mathrm{V},+\mathrm{Zn},+\% \mathrm{C}$ \\
\hline
\end{tabular}


Table 3 - Results for the $t$-tests of colony sites compared to the closest control site, separated by matrix. The simple, double and triple * marks stand for $p=0.05,0.01$ and 0.001 , respectively

\begin{tabular}{|c|c|c|c|c|c|c|c|c|c|c|c|c|c|c|c|c|c|c|c|c|c|}
\hline Main Location & Specific Location & Colony species & Matrix Species & $\mathrm{n}$ & $\mathrm{Hg}$ & As & $\mathrm{Cd}$ & Co & $\mathrm{Cr}$ & $\mathrm{Cu}$ & $\mathrm{Fe}$ & $\mathrm{Mn}$ & $\mathrm{Ni}$ & $\mathrm{Pb}$ & $\mathrm{Se}$ & $\mathrm{V}$ & $\mathrm{Zn}$ & $\delta^{13} \mathrm{C}(\%$ \%) & $\% \mathrm{C}$ & $\delta^{15} \mathrm{~N}(\%)$ & $\% \mathrm{~N}$ \\
\hline Half Moon & Half Moon & Pygoscelis antarcticus & Ramalina terebrata & 3 & $* *$ & * & & & & ** & & $* \star *$ & & * & & & & * & & ** & * \\
\hline \multirow{4}{*}{ KGI } & Cape Vauréal & Macronectes giganteus & Usnea antarctica & 3 & & $* *$ & $* *$ & * & & $* *$ & * & $* *$ & * & ** & & & & * & & & $* * *$ \\
\hline & Punta Hennequin & Catharacta $s p^{*}$ & Usnea antarctica & 3 & $* *$ & * & & & & & & * & & $\star * *$ & * & & * & *** & & & ** \\
\hline & Stenhouse & Larus dominicanus* & Usnea antarctica & 3 & & & & & & & & & & & & & & * & & & * \\
\hline & Turret Point & $\begin{array}{c}\text { Phalacrocorax atriceps } \\
\text { Pygoscelis adeliae }\end{array}$ & $\begin{array}{c}\text { Ramalina terebrata } \\
\text { Usnea antarctica }\end{array}$ & $\begin{array}{l}3 \\
3\end{array}$ & & $\star \star *$ & * & $* \star \star$ & * & & *** & ** & ** & ** & & * & * & $\begin{array}{c}* * * \\
*\end{array}$ & * & & \\
\hline \multirow{3}{*}{ Livingston } & \multirow{3}{*}{ Hannah Point } & \multirow{2}{*}{ Macronectes giganteus } & Ramalina terebrata & 2 & & $\star *$ & & * & & ** & ** & $* * *$ & & & & & & 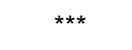 & & & \\
\hline & & & Turgidiusculum complicatulum & 1 & & $* * *$ & ** & $* * *$ & $\star *$ & ** & *** & 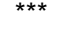 & & * & & & 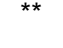 & *** & $* *$ & ** & *** \\
\hline & & Pygoscelis papua & Ramalina terebrata & 3 & * & ** & & * & & ** & * & $* * *$ & & * & & & & & & $* \star *$ & *** \\
\hline Nelson Island & Nelson Island & Daption capense** & Usnea aurantiaco-ater & 3 & & $* *$ & ** & & & * & * & * & & $* * *$ & & & $* *$ & ** & & & ** \\
\hline Penguin Island & Penguin Island & Sterna vittata & Usnea aurantiaco-ater & 3 & $\star \star \star *$ & & ** & & * & & & & * & $* * *$ & $* * *$ & * & * & & ** & * & \\
\hline
\end{tabular}




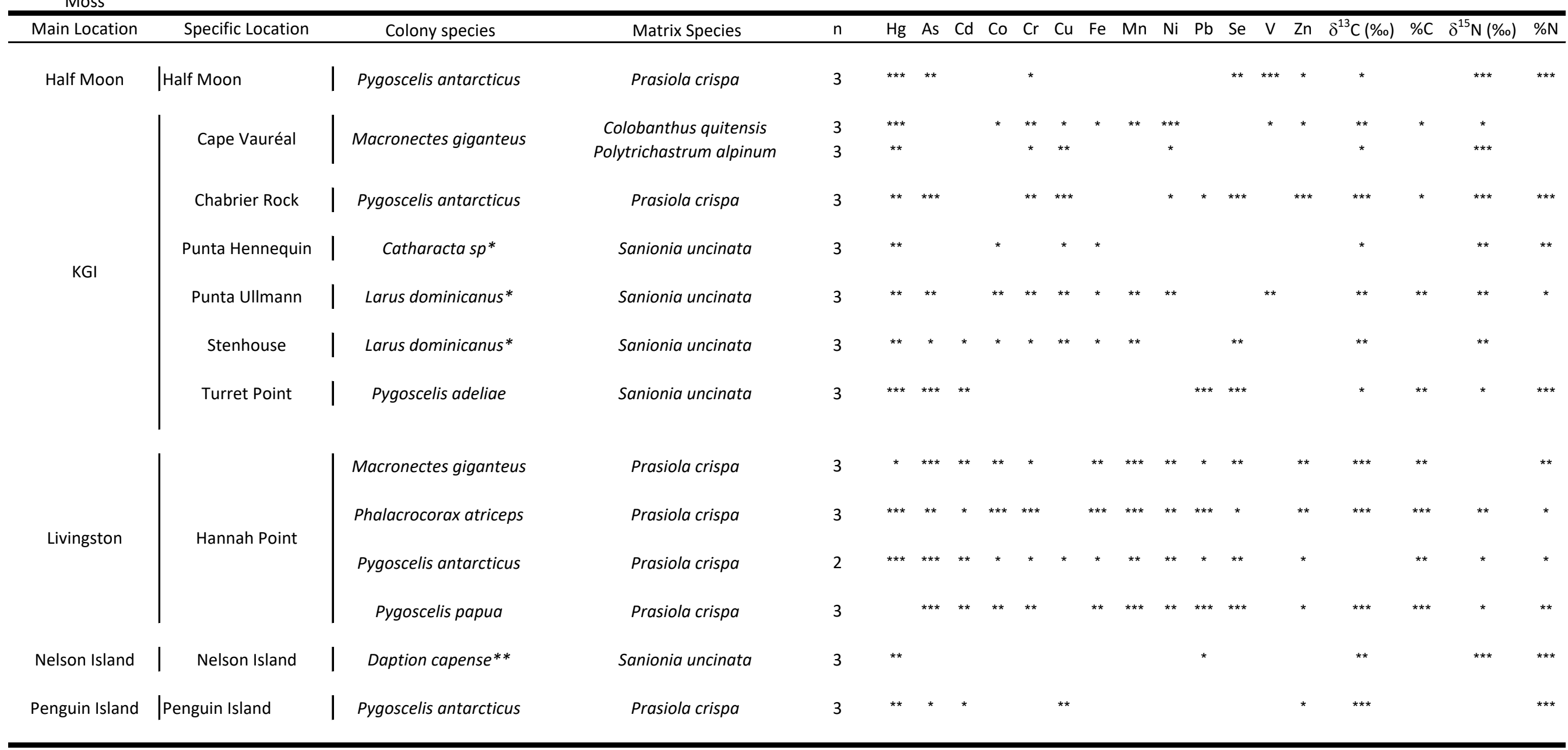




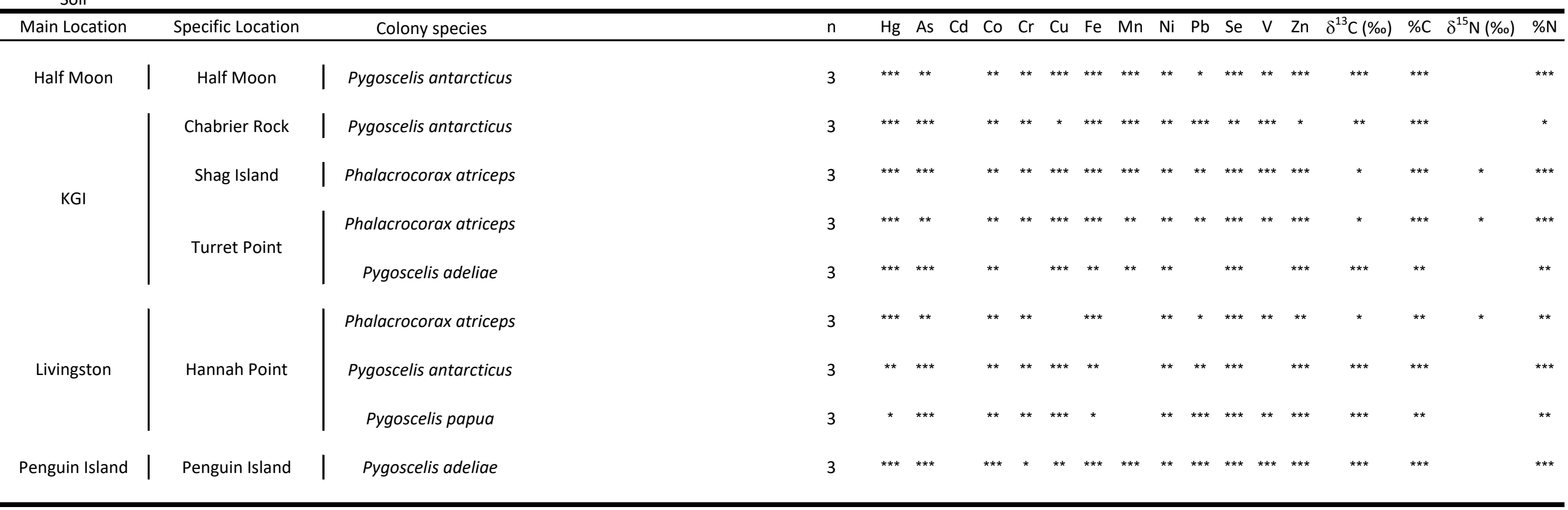

